\title{
Molecular imaging of cardiac remodelling after myocardial infarction
}

\author{
Daniel Curley ${ }^{1} \cdot$ Begoña Lavin Plaza ${ }^{2,4}(1) \cdot$ Ajay M. Shah ${ }^{3,4} \cdot$ René M. Botnar $^{2,4,5}$ \\ Received: 1 June 2017 / Revised: 17 November 2017 / Accepted: 8 January 2018 / Published online: 17 January 2018 \\ (c) The Author(s) 2018. This article is an open access publication
}

\begin{abstract}
Myocardial infarction and subsequent heart failure is a major health burden associated with significant mortality and morbidity in western societies. The ability of cardiac tissue to recover after myocardial infarction is affected by numerous complex cellular and molecular pathways. Unbalance or failure of these pathways can lead to adverse remodelling of the heart and poor prognosis. Current clinical cardiac imaging modalities assess anatomy, perfusion, function, and viability of the myocardium, yet do not offer any insight into the specific molecular pathways involved in the repair process. Novel imaging techniques allow visualisation of these molecular processes and may have significant diagnostic and prognostic values, which could aid clinical management. Single photon-emission tomography, positron-emission tomography, and magnetic resonance imaging are used to visualise various aspects of these molecular processes. Imaging probes are usually attached to radioisotopes or paramagnetic nanoparticles to specifically target biological processes such as: apoptosis, necrosis, inflammation, angiogenesis, and scar formation. Although the results from preclinical studies are promising, translating this work to a clinical environment in a valuable and cost-effective way is extremely challenging. Extensive evaluation evidence of diagnostic and prognostic values in multi-centre clinical trials is still required.
\end{abstract}

Keywords Myocardial infarction $\cdot$ Cardiac remodelling $\cdot$ Cardiovascular imaging $\cdot$ MRI

\section{Introduction}

Cardiovascular disease (CVD) is the most common cause of death worldwide with the 2013 Global Burden of Disease Study estimating that almost a third of all deaths globally are attributable to CVD [1]. CVD remains a large health burden reflected in its position at the forefront of clinical research.

Daniel Curley and Begoña Lavin Plaza have contributed equally to the preparation of this manuscript.

Begoña Lavin Plaza

begona.lavin_plaza@kcl.ac.uk

1 GKT School of Medicine, King's College London, London, UK

2 School of Biomedical Engineering and Imaging Sciences, King's College London, St. Thomas Hospital, 4th Floor, Lambeth Wing, London SE1 7EH, UK

3 School of Cardiovascular Medicine and Sciences, King's College London, London, UK

4 The British Heart Foundation Centre of Excellence, King's College London, London, UK

5 Escuela de Ingeniera, Pontificia Universidad Catolica de Chile, Santiago, Chile
Coronary heart disease carries significant morbidity and is the leading cause of death across all diseases of the circulatory system. Myocardial infarction (MI) is mainly caused by the rupture of an atherosclerotic plaque leading to a thrombus forming within the lumen of a coronary vessel, which in turn blocks the blood flow to distal myocardium [61]. Infarction leads to cardiac myocyte death and subsequent necrosis of the tissue in the infarcted area, attracting inflammatory cells that phagocytose dead cells and debris within the infarcted area [134]. Inflammation plays a crucial role in cardiac healing post-MI contributing to the initial repair of the infarct, with replacement of dead myocytes by scar tissue. However, in the longer term, it also contributes to changes in ventricular shape and function involving infarct expansion, thinning of the myocardium, ventricular dilatation, hypertrophy of the remote uninfarcted myocardium, and an overall decline in cardiac function. These changes are collectively known as adverse ventricular remodelling and are associated with an increased likelihood of heart failure and mortality $[92,145]$. Therefore, stratification of individuals at high risk of adverse ventricular remodelling post-MI may be of diagnostic, therapeutic, and prognostic benefits [62]. 
Current clinical imaging techniques are usually classified into anatomical and functional imaging. Plain film X-ray, computed tomography (CT), ultrasound, and magnetic resonance imaging (MRI) are mainly focused on structural changes, whereas nuclear medicine scans such as single proton-emission computed tomography (SPECT) and positron-emission tomography (PET) aim to provide functional aspects.

Molecular imaging is a novel technique which aims to visualise pathological processes at a molecular and cellular levels. Initially, molecular imaging was used for pharmaceutical development; however, recent research has focused on the use of molecular imaging as a clinical tool to stratify those patients at risk of developing disease and to provide early diagnosis [103]. This non-invasive, safe, and, therefore, attractive alternative to other invasive approaches such as tissue biopsy allows visualisation and measurement of underlying disease processes. Cardiac molecular imaging mainly involves imaging probes which are detectable using SPECT/PET and MRI, which are the focus of this review.

\section{Pathophysiology of post-MI cardiac remodelling}

During MI, cardiomyocytes die as a result of oxygen deprivation due to blockage of a coronary artery which limits the blood supply to the cells, resulting in transmural ischaemia [18]. Under hypoxic conditions, cardiomyocytes undergo anaerobic respiration, destabilization of the cell membrane, and finally cell death $[6,73,151]$. Reperfusion after the acute event exacerbates existing oedema which gradually resolves as the myocardium repairs [158]. The infarct commences in the subendocardial layers in the centre of the area at risk, that is, the perfusion region of the coronary artery which has been occluded, and evolves towards the subpericardial layers and the boarder of the area at risk in a wavefront pattern if coronary occlusion persists $[43,109,110]$.

Infarct size is a major indicator of post-MI remodelling, subsequent heart failure [44], and eventually prognosis [23, $94,95]$. It is determined by the size of the area at risk, the duration of coronary occlusion, and resulting ischaemia and the magnitude of collateral blood flow [54]. Temperature also impacts on the infarct size in the animal model [82] whereas the consensus on the haemodynamic situation, particularly heart rate [42], and myocardial oxygen demands have changed recently and it is now believed that they are only of limited importance regarding infarct size [43, 124].

The infarcted myocardium is morphologically characterised by myofibrillar contraction bands, swollen and ruptured mitochondria, destruction of cardiomyocyte membranes, microvascular destruction, haemorrhage, and inflammation [54]. These histological features reflect necrosis and become more apparent during reperfusion $[60,109,110]$. Necrotic cell death has many effects in infarcted myocardium [54], and different processes contribute such as excessive myofibrillar contractions [73, 104, 105, 136], digestion of the cytoskeleton and sarcolemma [56], and increased production of reactive oxygen species (ROS) [75, 118].

Contrary to necrosis, more regulated modes of cell death such as apoptosis, autophagy and necroptosis also occur in myocardial infarction, although their actual contribution to the final infarct size is still unclear $[13,54,55,64,66,72$, 101, 146]. Apoptosis is an energy-dependent form of cell death with DNA disintegration and without an associated inflammatory response $[7,45,71,101,154]$. Autophagy is also a regulated mode of cell death characterised by lysosomal protein degradation and protein recycling, particularly mitochondrial proteins. Paradoxically, autophagy is considered to have a protective effect [107], although its role in human myocardial ischaemia is less well known [33, 122]. Necroptosis, as its name suggests, has similarities to both necrosis and apoptosis, but is distinctly regulated by activation of specific receptor-interacting protein kinases [100, 161].

After an acute MI, the most effective strategy for reducing the size of the infarct and improving clinical outcome is timely and successful myocardial reperfusion. However, the restoration of blood flow to the ischaemic myocardium can itself induce injury [8, 44, 124, 159]. In the last 30 years, many attempts have been evaluated to reduce the effects of reperfusion injury, processes known as pre-conditioning and post-conditioning [40,141]. Whereby the myocardium is exposed to brief periods of ischaemia and reperfusion prior to (ischaemic pre-conditioning) [97, 124] or following an acute thrombotic MI (ischaemic post-conditioning) [124, 160].

The healing process after MI consists of inflammatory, proliferative, and maturation phases. The inflammatory phase involves the production of chemokines and cytokines which attract leucocytes to the infarcted zone. White blood cells such as neutrophils and macrophages phagocyte dead cells and extracellular matrix (ECM) debris. Then, during the proliferative phase, monocytes/macrophages contribute to tissue granulation by releasing cytokines and growth factors, suppressing inflammatory mediators and promoting angiogenesis, fibroblast growth, and production of ECM proteins. Finally, during the maturation phase, fibroblasts and vascular cells undergo apoptosis and a mature collagen scar is formed [15, 29, 145].

A further post-MI consequence is the stimulation of the renin-angiotensin-aldosterone system (RAAS), which leads to the activation of a family of proteolytic enzymes in the heart, named matrix metalloproteinases (MMPs), which are responsible for the degradation of extracellular proteins within the myocardium $[85,140]$. In physiological 
conditions, MMPs are in the myocardium in an inactivated form. However, after MI, a significant decrease of tissue inhibitory MMPs (TIMPs) leads to MMPs' activation [16, 156]. The main consequences of these cellular mechanisms include infarct expansion, left ventricular dilatation, and myocardial thinning, all of which contribute to heart failure (Fig. 1).

The size of the infarct zone and the level of perfusion, among other factors, affect the progression of these events. However, there is a direct correlation with early, aggressive immune/inflammatory responses associated with high concentrations of leucocytes and adverse remodelling leading to a poor prognosis $[36,63,67,106,145]$. Therefore, the ability to measure and visualise cardiac remodelling at the cellular and molecular levels may produce useful clinical information to tailor individual management plans for patients [62].

\section{Current cardiac imaging techniques}

Almost all imaging modalities can be used to assess cardiac pathology. Although plain X-ray, CT, and ultrasound are currently used in clinical practice for cardiac imaging, these modalities are rarely used for molecular imaging. In this review, we will focus on SPECT, PET, and MRI, as they are the mainstay of molecular cardiac imaging.

Fig. 1 Schematic showing the gross changes in adverse cardiac remodelling post-MI (figure adapted from [143])

\section{Single photon-emission computed tomography}

SPECT imaging uses a gamma camera that rotates around the patient, sampling the radiation at various points to acquire a number of images which can then be reconstructed to produce a 3D image. Imaging of myocardial perfusion using SPECT is known as a rest/stress test. Clinically approved radioactive tracers such as thallium-201 $\left({ }^{201} \mathrm{Tl}\right)$ and technetium-99 $\mathrm{m}\left({ }^{99 \mathrm{~m}} \mathrm{Tc}\right)$ sestamibi or $\left({ }^{99 \mathrm{~m}} \mathrm{Tc}\right)$ tetrofosmin, are intravenously administered to the patient, taken up by cardiomyocytes that represent their initial distribution and this is seen as a marker for myocardial perfusion [142]. Image acquisition is performed while the patient is at rest and also while under stress, allowing the evaluation of myocardial viability and perfusion. Stress conditions can be achieved physically (e.g., exercise) or pharmacologically (e.g., adenosine or dobutamine) if the patient has poor exercise tolerance. Tomographic slices are then processed using iterative reconstruction with, e.g., a Weiner smoothing filter [80]. The final images are reconstructed in the short axis, vertical long axis, and horizontal long axis of the heart for both the resting and the stressed states and are quantified using a bull's-eye plot [70].

SPECT is widely available and is clinically recommended for diagnostic and prognostic purposes for patients
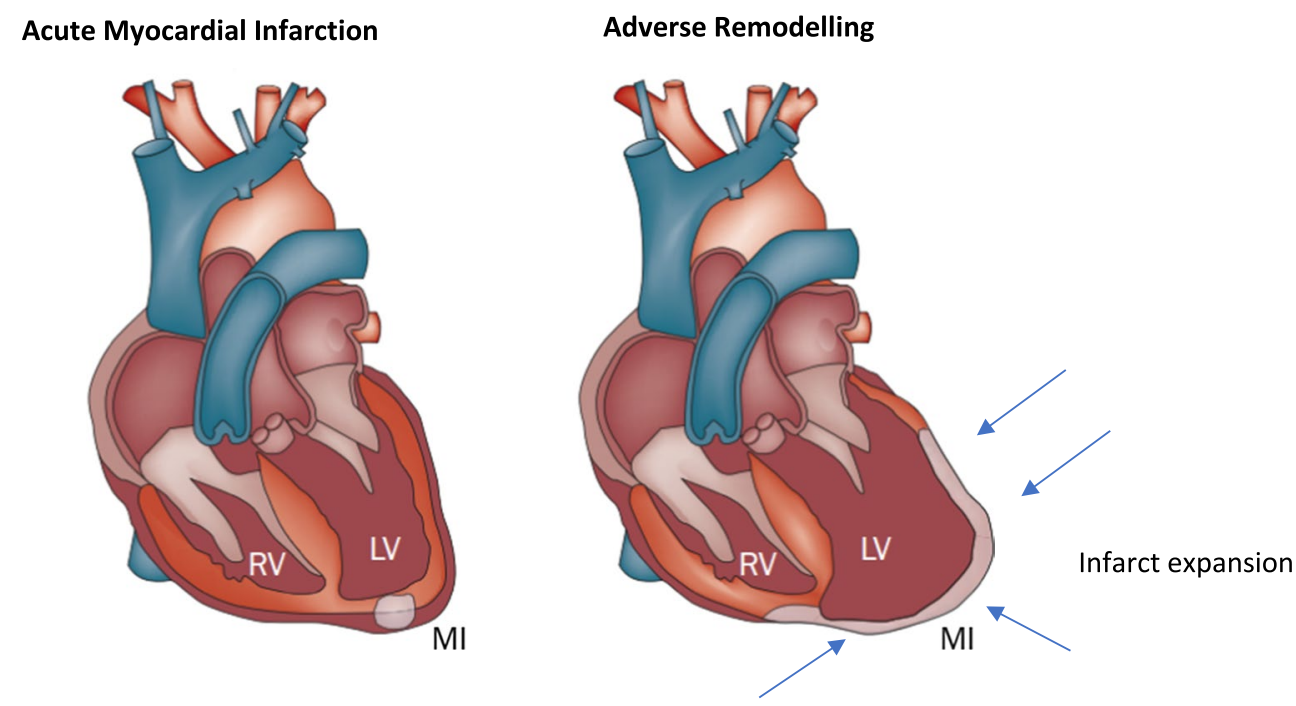

Inadequate healing after MI

- Infarct expansion

- $\quad$ LV dilatation

- Myocardial thinning

- $\quad$ Heart failure 
with suspected intermediate CVD [27]. However, its low spatial resolution and the use of ionising radiation represent a limitation, especially in patients who need repeated follow-up imaging.

\section{Positron-emission tomography}

PET imaging differs slightly to SPECT, as the detectors are positioned in a stationary ring around the patient and PET tracers are biologically active allowing for assessment of, e.g., myocardial viability. Naturally occurring biological molecules can be radioactively labelled and administered to the patient. Clinical cardiac PET tracers include ${ }^{13} \mathrm{~N}$-ammonia, ${ }^{15} \mathrm{O}$-water, and ${ }^{82}$ rubidium for myocardial perfusion and ${ }^{18} \mathrm{~F}$-fluorodeoxyglucose (FDG) for cardiomyocyte metabolism and viability. The radioactive tracer decays, emitting a positron which travels in the tissue for a short distance before interacting with an electron, causing an annihilation event producing two $511 \mathrm{keV}$ photons moving in opposite directions. The PET system detects these photons and, therefore, the localisation of the annihilation event. Correction for attenuation is a standard practice in PET imaging to improve accuracy and quantify concentrations of radioactive tracers [34]. A recent meta-analysis showed that sensitivity and specificity to detect obstructive CVD-induced ischaemia with PET imaging was $84-92 \%$, while $81-85 \%$ was achieved using SPECT, demonstrating the higher diagnostic value of PET [59]. However, perhaps, the most important advantage of using PET compared to SPECT is its ability to use ${ }^{18} \mathrm{~F}$ FDG to measure glucose metabolism within cardiomyocytes alongside myocardial perfusion. The combination of an ${ }^{18}$ F-FDG-PET metabolic scan together with a PET/SPECT perfusion scan enables to distinguish between infarcted and viable myocardial tissues [34].

\section{Cardiac magnetic resonance}

Cardiac magnetic resonance (CMR) imaging is a non-ionising imaging modality, where patients are placed in a large magnetic field. Hydrogen atoms inside the patient align with the magnetic field and are perturbed by short radiofrequency (RF) pulses to generate an MR signal that can be spatially encoded with the help of strong magnetic field gradients. The combination of RF pulses and magnetic field gradients is known as a pulse sequence. After perturbation (also called excitation), the precessing hydrogen atoms emit a signal that can be measured with a receiver coil and spatially encoded in the presence of magnetic field gradients. Subsequent reconstruction of the MR signal which acquired in a 2D or 3D space, also referred to k-space, typically by a Fourier transform, reveals spatially resolved information about the structure being imaged [86]. CMR is a well-established cardiac imaging technique that allows the assessment of the anatomy and function of cardiac tissue through visualisation of cardiac tissues due to differences in $\mathrm{T} 1$ and $\mathrm{T} 2$ relaxation time and blood flow and by employing cine imaging [91, $147,152]$. In addition, CMR can identify the area at risk after MI due to the oedematous nature of this region, as T1-weighted and T2-weighted images are both sensitive to water content (long T1 and long T2) [30, 47]. However, the use of T2-weighted MRI together with LGE quantification to assess oedema has been criticized due to the spatial and temporal dynamics of the oedema after reperfusion. In addition, motion artefacts and/or artificial hyperintensities could affect the quantification of oedema [46]. Furthermore, the use of contrast agents significantly improves the detection and evaluation of injured areas. Gadolinium-based contrast agents can be monitored on their first-pass to assess cardiac perfusion; areas that are poorly perfused will have reduced signal intensity on T1-weighted images as less gadolinium will be present in this area [58]. Gadolinium-based contrast agents can also be used to determine areas of irreversible damage, as it clears from necrotic and fibrotic tissue much slower than healthy tissue [14] and thus leads to a late gadolinium enhancement (LGE) effect.

\section{Molecular imaging techniques in post-MI remodelling}

Molecular imaging is a non-invasive imaging technique to detect biological processes in vivo. This is achieved with the use of tracers that bind to specific biological molecules that can be visualised by the imaging system [103].

Methods involved in nuclear molecular imaging to visualise post-MI cardiac remodelling are similar to the standard nuclear medicine techniques previously discussed, whereby radioactive molecules are taken up by cardiomyocytes to visualise myocardial perfusion. However, novel techniques now use radioactively labelled tracers that target specific molecules involved in the cellular process of cardiac remodelling.

Conversely, CMR has traditionally been used for visualisation of whole organ anatomy, function, perfusion, and fibrosis, as described above. However, a recent shift within the literature and advancement of nanotechnology and new imaging probes has enabled molecular imaging of specific targets using MRI. Imaging agents have been developed to visualise specific targets involved in the cellular and molecular pathways during post-MI remodelling. Gadolinium chelates have been used as extracellular MRI contrast agents for years. More recently, gadolinium chelates have been successfully employed for imaging highly abundant targets such as albumin, fibrin, collagen, and elastin. 


\section{Extracellular matrix}

An interesting target to evaluate post-MI alterations is the activation of MMPs, in particular MMP-2 and MMP9, as they are involved in ECM degradation and cardiac remodelling post-MI $[17,131,155]$. It has been shown that radiolabelling molecules that target MMPs allow visualisation of activated MMP post-MI in vivo. Su et al. [132] showed in a murine model of MI that radiolabelled MMPs can be visualised using SPECT/CT in areas of infarction, although there is some signal within non-ischaemic areas of the heart, demonstrating the global MMP activation and remodelling (Fig. 2). This study, like many others, suggests that activation of MMPs occurs mainly in areas of infarction and highlights the potential for evaluation of ventricular remodelling.

In addition, collagen has been targeted using CMR. EP-3533, a gadolinium-based contrast agent, has been studied in mouse models of MI [11, 41]. This imaging probe is of small molecular weight and was developed to visualise the collagen within post-MI scar. This differs slightly from the standard gadolinium chelates that can visualise the scar through gross changes within the cardiac tissue. Hyperintensity was seen, $10 \mathrm{~min}$ after injection of EP-3533, and its washout times were significantly longer than that of GdDTPA in areas of scar and in normal myocardium. Therefore, EP-3533 is able to image fibrosis in a mouse model of post-MI scarring (Fig. 3).
Fig. 2 Thalium-201 perfusion imaging, Tc-99m-labelled MMP imaging, and fused images before (SHAM), 1 week and 3 week post-MI using SPECT/ CT. Arrows show infarct zone, which is poorly perfused, where MMPs are detected [132]

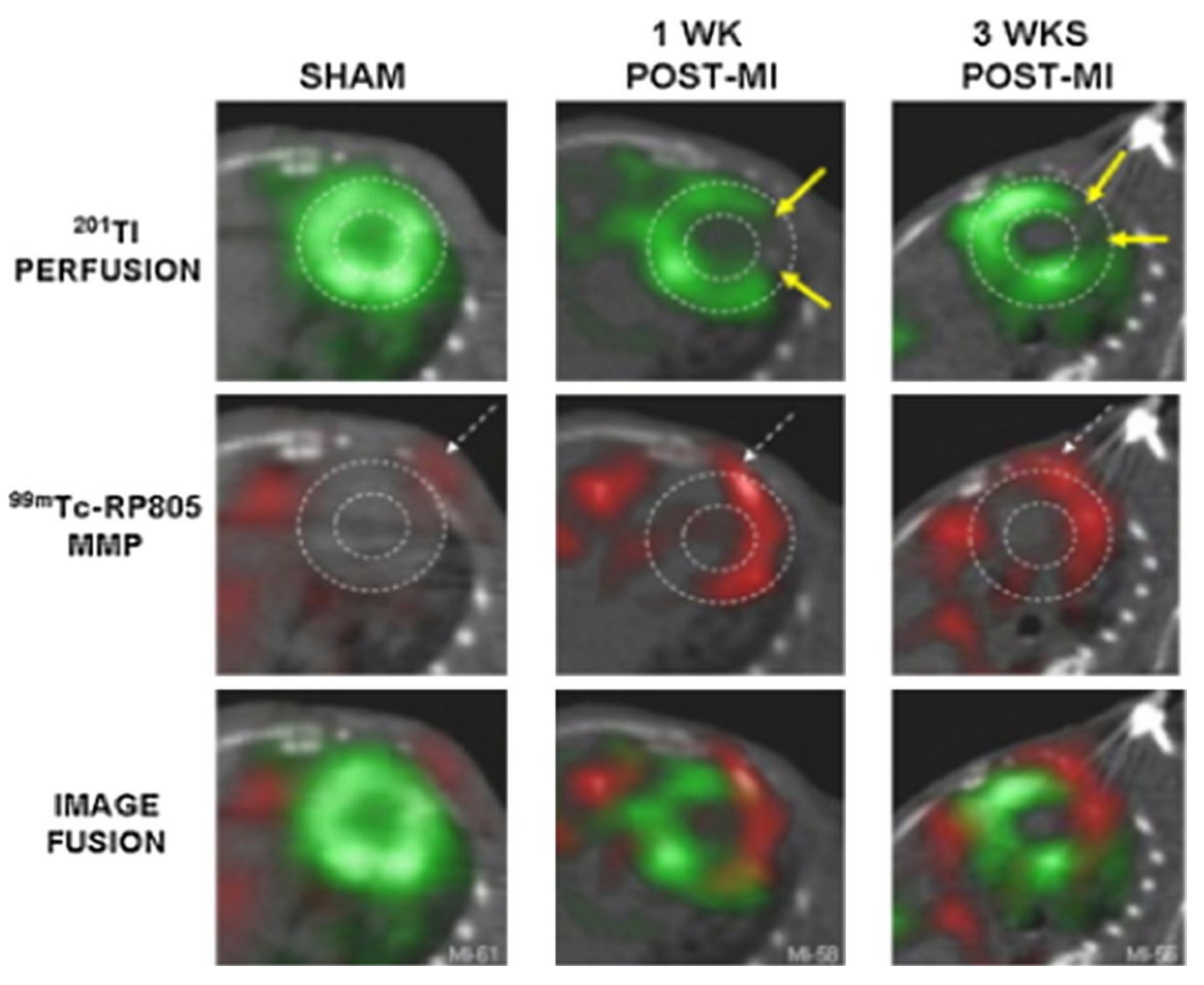

Fig. 3 T2-weighted CMR image before injection of EP-3533 (a) and $\mathbf{b}$ an inversion recovery CMR image 40 min after the injection of EP-3533. The arrow highlights the hyper-intense region indicating high levels of collagen, therefore, scar [11]
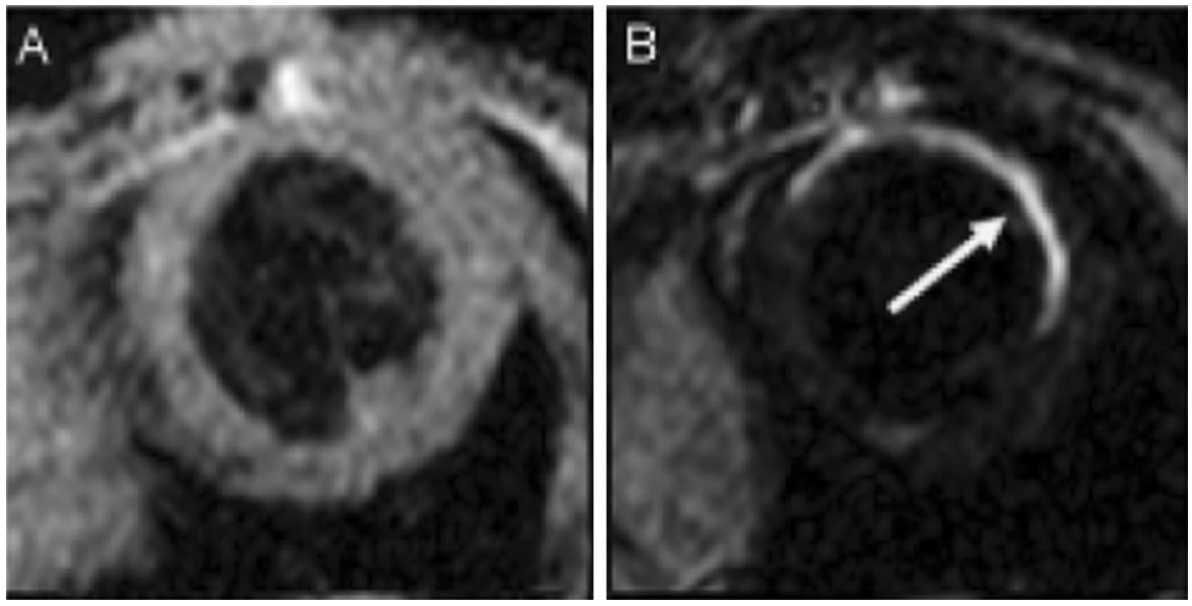


\section{Renin-angiotensin-aldosterone system}

In addition to the ECM, the renin-angiotensin-aldosterone system (RAAS) has also been proposed as a possible target. Various factors may activate the RAAS such as a loss of blood volume or a drop in blood pressure (as in haemorrhage or dehydration). Local cardiac levels of molecules involved in the RAAS are increased in post-MI states, being potential targets for imaging ventricular remodelling post-MI [102]. Owing to the pivotal role that angiotensin-converting enzyme (ACE) inhibitors play in CVD treatment, ACE inhibitor-based tracers are an attractive imaging approach to monitor disease progression and therapeutic interventions. Thus, several targeted radioactively labelled pharmaceuticals have been developed [120]. ${ }^{18} \mathrm{~F}$-captopril [53] and ${ }^{18} \mathrm{~F}$-flurobenzoyl-lisinopril [79], two radiolabelled ACE inhibitors, have shown increased levels in the infarcted area using PET imaging [20]. Lisinopril has also been successfully labelled with ${ }^{99 \mathrm{~m}} \mathrm{Tc}$ in rats $[24,25]$ and it is thought that it has higher affinity for tissue ACE than captopril, as shown in an experimental in vitro study [133]. These tracers allow distribution assessment while maintaining the therapeutic inhibition of ACE with angiotensin II type-1 receptors $\left(\mathrm{AT}_{1} \mathrm{R}\right)$ in vivo $[19,121]$.

A PET tracer ${ }^{11} \mathrm{C}$-zofenoprilat (a derivative of the ACE inhibitor zofenopril) has also been described and evaluated in humans; however, it accumulates mainly in tissues with high levels of ACE, such as the liver, lungs, kidneys, and gallbladder. Therefore, the use of this tracer in cardiac imaging is of little interest [88].

Other authors have described the use of $\mathrm{AT}_{1} \mathrm{R}$ as imaging targets for heart failure and LV remodelling. Radiolabelled tracers include ${ }^{11} \mathrm{C}-\mathrm{MK}-996,{ }^{11} \mathrm{C}-\mathrm{L}-155884$, SK-1080, and ${ }^{11}$ C-KR31173 an analogue of SK-1080 [35, $77,89,90,135]$. In addition, uptake of losartan, an angiotensin receptor blocker labelled with ${ }^{99 \mathrm{~m}} \mathrm{Tc}$ for SPECT imaging, has been shown to increase by 2.4 -fold in postMI mouse models when compared to controls [150].

The PET agent ${ }^{11} \mathrm{C}-\mathrm{KR} 31173$ has been effective in a rat MI model showing a peak uptake in the infarct zone at 1-3 week post-surgery. This effect can be blocked entirely using the $\mathrm{AT}_{1} \mathrm{R}$ antagonist valsartan, in comparison with the ACE inhibitor enalapril which did not affect $\mathrm{AT}_{1} \mathrm{R}$ density, providing a platform to predict the risk for ventricular remodelling and to monitor the efficacy of antiRAAS drug therapy [48]. Furthermore, healthy pig studies of ${ }^{11} \mathrm{C}$-KR31173 confirmed myocardial uptake with regional homogeneousness and $\mathrm{AT}_{1} \mathrm{R}$ specificity with the use of blocking experiments. This study included the first human trial in which there were no adverse effects across all subjects $(n=4)$. The results of the human studies showed detectable and specific myocardial retention of ${ }^{11} \mathrm{C}-\mathrm{KR} 31173$, though at a lower level than pigs. Myocardial retention disappeared after blockage with olmesartan, an $\mathrm{AT}_{1} \mathrm{R}$ antagonist, demonstrating its affinity for the $\mathrm{AT}_{1} \mathrm{R}$ [31]. Inter-species differences have been reported within the literature with rats [48] and mice [150] showing strong upregulation of $\mathrm{AT}_{1} \mathrm{R}$ in infarcted myocardium in contrast to pigs, where this is less pronounced [31]. Human subjects show significantly lower levels of absolute retention of $\mathrm{AT}_{1} \mathrm{R}$ than pigs. Whether this is due to further inter-species differences or the effects of anaesthesia in animals has not yet been clarified [31]. The potential for imaging the $\mathrm{AT}_{1} \mathrm{R}$ remains an exciting prospect, especially given the recent use of ${ }^{11} \mathrm{C}-\mathrm{KR} 31173$ in humans indicating the potential safety of the tracer which will require further evaluation in clinical trials.

\section{Angiogenesis}

One of the most important biological processes during the proliferation phase of myocardial healing after ischaemic injury is microvascular angiogenesis, which consists of the development of new blood vessels from pre-existing vasculature [112]. Angiogenesis is stimulated by increased levels of vascular endothelial growth factor (VEGF) and basic fibroblast growth factor (bFGF), which are released in response to the infarction. Imaging targets of angiogenesis include $\alpha_{v} \beta_{3}$ integrin [49] and VEGF receptors [115].

$\alpha_{v} \beta_{3}$ integrin is essential for endothelial cell propagation and survival. It is generally not expressed on mature vessels in physiological conditions; however, it is expressed on endothelial cells during vasculogenesis and angiogenesis as a response to angiogenic growth factors [22]. Integrins recognise proteins and surface molecules through short peptide sequences such as Arg-Gly-Asp (RGD) [37]. Several studies have been done to explore tracers targeting $\alpha_{v} \beta_{3}$ integrin in tumour models [49]. However, some studies have been focused on the evaluation of radiolabelled tracers targeting $\alpha_{v} \beta_{3}$ integrin in cardiac angiogenesis, including ${ }^{18} \mathrm{~F}$-galactoRGD and ${ }^{99 \mathrm{~m}}$ Tc-RAFT-RGD [21].

${ }^{18} \mathrm{~F}$-galacto-RGD is a PET tracer that binds $\alpha_{\mathrm{v}} \beta_{3}$ integrin developed by Haubner et al. [38, 39]. Higuchi et al. [49] demonstrated in rats that ${ }^{18} \mathrm{~F}$-galacto-RGD levels, rise 3 days, peak around 3 weeks, and return to baseline levels 6 months after MI. Makowski et al. [84] concurred and showed that ${ }^{18} \mathrm{~F}$-galacto-RGD levels are raised in patients 2 weeks after MI. Furthermore, correlation between early post-MI uptake of this tracer and the absence of significant LV remodelling after 12 weeks follow-up has been demonstrated by Sherif et al. [119].

However, the production of ${ }^{18} \mathrm{~F}$-galacto-RGD is challenging due to the multistep synthesis and the need for an onsite cyclotron. Therefore, alternative RGD tracers have been 
proposed such as the one-step labelled PET tracer ${ }^{18} \mathrm{~F}$-AlFNOTA-PRGD2 [32] which shows a similar pattern of tracer uptake in the infarct area and significantly higher tracer levels than those reported using ${ }^{18} \mathrm{~F}$-galacto-RGD [49]. The in vivo performance and easy production method of this PET tracer may facilitate its future clinical translation. It has also been used successfully to visualise angiogenesis after VEGF gene therapy and bone-marrow stem-cell therapy in rats [10].

A further two gallium-based tracers have been studied, again to offer an alternative for the challenges faced by the production of ${ }^{18} \mathrm{~F}$-galacto-RGD, as gallium tracers may be beneficial to sites which do not have a cyclotron close by. Laitenen et al. have shown both ${ }^{68} \mathrm{Ga}$-NODAGA-RGD and ${ }^{68} \mathrm{Ga}$-TRAP(RGD) ${ }_{3}$ to be as effective as ${ }^{18} \mathrm{~F}$-galactoRGD in a rat model [74]. Although the prime importance of these tracers is the imaging quality, these more practical aspects of introducing these tracers into clinical practice will be a decisive factor into deciding which of these tracers to take forward into clinical trials and ultimately translate to the bed side.

${ }^{99 \mathrm{~m}} \mathrm{Tc}-\mathrm{RAFT}-\mathrm{RGD}$ is an SPECT tracer that also binds $\alpha_{v} \beta_{3}$ integrin and has been validated to image myocardial angiogenesis on rat models in vivo [21]. Figure 4 highlights the ability of this tracer to identify areas of active angiogenesis when compared with ${ }^{201} \mathrm{Tl}$ perfusion scans that identify areas of ischaemia. These results showed the maximum quantitative uptake in the infarct area at 2 weeks after MI which is comparable to Higuchi et al. [49] using the PET tracer ${ }^{18} \mathrm{~F}$-galacto-RGD 1 or 3 weeks following reperfusion in a similar murine model.
Meoli et al. have evaluated an SPECT tracer ${ }^{111}$ In-RP748, which shows a similar increase in tracer activity to that of ${ }^{99 \mathrm{~m}}$ Tc-RAFT-RGD in the re-perfused zone post-MI [93]. The authors also showed an infarct-to-normal zone tracer activity ratio of 1-1.6, with dual isotope SPECT imaging of ${ }^{111} \mathrm{In}$ RP748 and ${ }^{99 \mathrm{~m}} \mathrm{Tc}-\mathrm{MIBI}$ in a canine model.

CMR imaging with $\alpha_{v} \beta_{3}$-targeted paramagnetic nanoparticles is currently an active area of research, and although this is not yet used to assess post-MI remodelling, it has been studied in the context of atherosclerosis $[9,157]$.

All of the above tracers are aimed at targeting the $\alpha_{v} \beta_{3}$ integrin signal which is actually a rather controversial topic. This is owing to the signal may not solely represent angiogenesis, but also myofibroblast and leucocyte activity, although more studies need to be performed to evaluate these effects $[4,50,143,144]$. Furthermore, the post-MI uptake of an SPECT tracer targeting $\alpha_{v} \beta_{3} / \beta_{5}$ has been shown to predict the extent of fibrosis 1 year later, which highlights the potential of this signal to be used to visualise myofibroblasts [149].

VEGF is an abundant and potent angiogenic agent and its receptors are potentially good targets for imaging of angiogenesis. ${ }^{111}$ In-labelled recombinant human VEGF $_{121}$ was used to visualise areas of active angiogenesis in a rabbit model with unilateral hind limb ischaemia. In this study, tracer levels were detected using scintillation well counting and planar scintigraphy studies, demonstrating that the tracer uptake in ischaemic muscle was significantly increased, 10 days after occlusion [81]. More recently, ${ }^{64} \mathrm{CU}-\mathrm{DOTA}-$ VEGF $_{121}$ has been explored as a PET tracer, targeting VEGF receptors in a rat model of MI. In this study, tracer levels

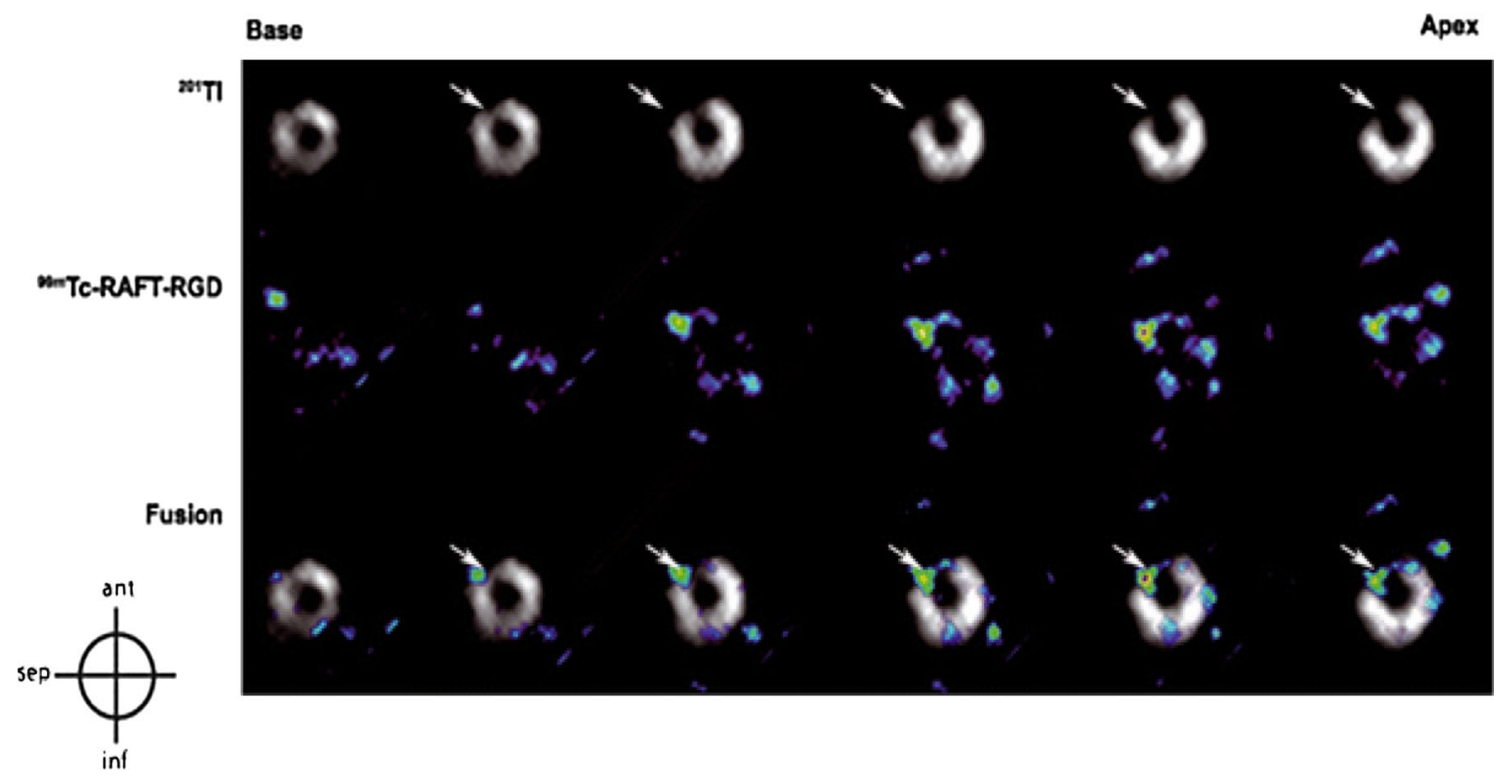

Fig. 4 Myocardial short-axis images from base to apex with ${ }^{201} \mathrm{Tl}$ perfusion SPECT, ${ }^{99 \mathrm{~m}} \mathrm{Tc}-\mathrm{RAFT}$-RGD SPECT scan and fused images. The arrows highlight areas of infarct (figure adapted from [21]) 
peaked 3 days post-MI and decreased over time until it reached baseline levels on day 24 [115].

There are clearly many tracers, predominantly radiolabelled PET and SPECT tracers that have been evaluated in animal models to visualise angiogenesis for the purpose of post-MI remodelling, with some having even been tested on humans. There is a growing consensus that this technology could be of pronounced clinical benefit to define the risk of patients who may develop cardiac remodelling post-MI. There is, therefore, a need for further evaluation of these tracers in clinical trials. However, many challenges, as discussed through this section, have been identified in bringing these tracers to the bedside and researchers will have to choose which tracer to invest in for their studies. Furthermore, the specificity of the $\alpha_{v} \beta_{3}$ integrin to angiogenesis has been questioned which should play a role in future studies.

\section{Apoptosis}

Apoptosis can also be evaluated using imaging techniques by targeting the protein annexin $\mathrm{V}$ which is expressed on the cell surface of apoptotic cells [51]. Kietselaer et al. [66] successfully labelled annexin $\mathrm{V}$ to ${ }^{99 \mathrm{~m}} \mathrm{Tc}$, allowing for visualisation of apoptosis using SPECT, showing a direct correlation between annexin $\mathrm{V}$ uptake and deterioration in left ventricular function.

First, MRI approaches to image apoptosis were reported by Sosnovik et al. [127] using AnxCLIO-Cy5.5, a novel annexin-based magneto-optical nanoparticle. They reported a significant decrease in myocardial $\mathrm{T} 2 *$ compared to the unlabelled control probe (Fig. 5). In addition, a significant correlation was reported between the local extent of signal loss and the infarcted area, suggesting that the AnxCLIOCy5.5 probe accumulated specifically in regions of injured and apoptotic myocardium. More recently, Sosnovik et al. [128] presented a dual contrast-molecular MRI approach to simultaneously evaluate apoptosis and necrosis. In this study, AnxCLIOCy5.5 was used to image apoptosis and a gadolinium chelate, Gd-DTPA-NBD, was used to detect cardiac necrosis. Interestingly, only $21 \%$ of the myocardium with active apoptosis colocalizes with the Gd-DTPA-NBA signal, suggesting that viable myocardium may be present within the apoptotic area.

\section{Inflammation}

During ischaemic injury, the infarct area becomes oedematous due to increased capillary permeability and macrophages migrate to the infarct zone, where they accumulate. Magnetic iron oxide nanoparticles (MNPs) are ideal for imaging scarce molecular targets within cardiac tissue [130], as they are very small (nanometres), have high magnetic relaxation properties, and are designed to be biologically inert [126]. During the inflammatory phase, MNPs extravasate into the infarcted myocardium, permitting them to accumulate at the imaging target. MNPs are recognised as foreign bodies and are taken up by phagocytes in the infarct zone and, therefore, can be used to visualise inflammation within the myocardium. A T2*-weighted gradientecho sequence is performed and MNP accumulation is seen as hypo-intense regions within the image, due to the high relaxivity of MNPs.

An additional probe to image the inflammatory phase is the use of perfluorocarbon nanoemulsions $\left({ }^{19} \mathrm{~F}\right)$. These particles are avidly taken up by macrophages which then migrate to the infarcted zone. Low-resolution ${ }^{19} \mathrm{~F}$-MRI has been validated to visualise macrophages in a post-MI state. Macrophage accumulation was detected within the infarcted area over time [26].

An additional approach to image inflammation is targeting myeloperoxidase (MPO), an enzyme produced by neutrophils and monocytes that has been correlated with an adverse effect on LV remodelling and function [148]. Gadolinium-labelled MPO has been validated for assessment of MPO activity in post-MI myocardium with a significant increase 2 days after myocardial injury [98].
Fig. 5 Post-MI state in mouse models injected with AnxCLIO-Cy5.5 (a) and a control probe inact_CLIO-Cy5.5 (b). Significant hypo-intensity can be seen with AnxCLIO-Cy5.5 (a), depicted by yellow arrows. There are no areas of significant uptake seen using the control probe (b). Regions of hypointensity represent the visualisation of active apoptosis [128]
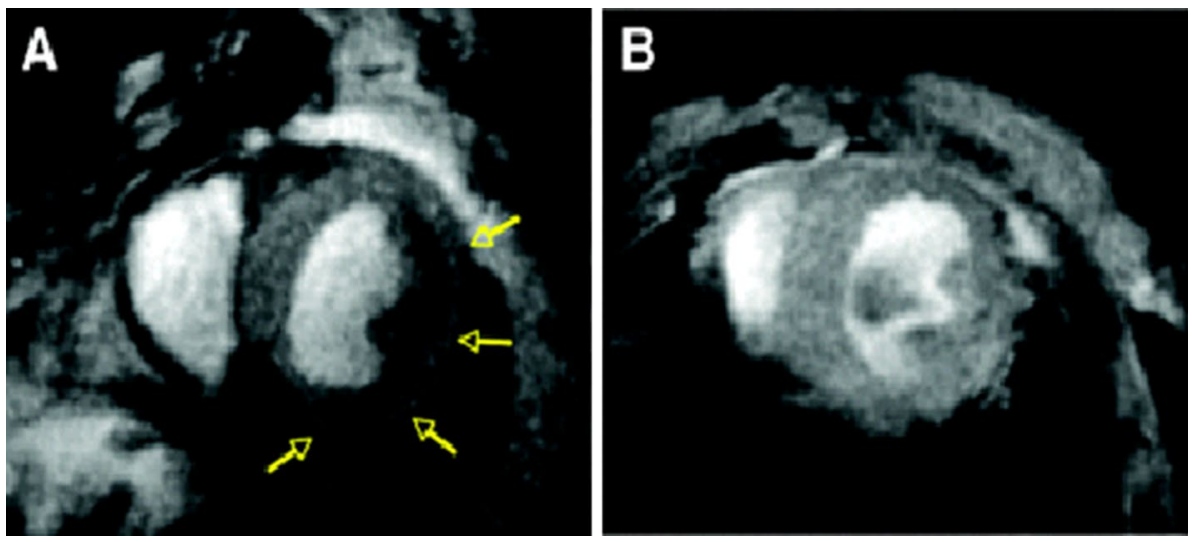
Several preclinical studies have shown how ${ }^{18}$ F-FDGPET can be used to evaluate the innate immune response after MI $[57,78,116]$. Using a similar approach ${ }^{18}$ F-FDGPET uptake has been successfully correlated inversely with the functional outcome 6 month post-MI [114], presenting ${ }^{18} \mathrm{~F}$-FDG-PET uptake as a possible marker of myocardial outcome. However, imaging of inflammation using ${ }^{18} \mathrm{~F}-\mathrm{FDG}$ has few limitations. First, ${ }^{18} \mathrm{~F}$-FDG is a glucose analogue and can be used for the metabolism of different cells. Moreover, ${ }^{18} \mathrm{~F}$-FDG is generally used to evaluate myocardial viability [117] and metabolism response to hypoxia [2]. Therefore, imaging inflammation using ${ }^{18} \mathrm{~F}-\mathrm{FDG}$ in the heart requires the suppression of cardiomyocytes by dietary pre-preparation of the patients [138]. However, it has not been shown how reliable this method is to suppress signal coming from viable cardiomyocytes after MI or hibernating myocardium, among others. Other limitations of the use of ${ }^{18} \mathrm{~F}-\mathrm{FDG}$ are that it is not possible to differentiate between different subpopulations of inflammatory cells, which play different roles in myocardial healing. Therefore, it is crucial to develop new targeted tracers to detect the different subpopulations of inflammatory cells. In light of that, it has been proven in cells, animals and men that the tracer ${ }^{11} \mathrm{C}$-Methionine is taken up by inflammatory cells, preferentially inflammatory macrophages [137]. The absence of cardiomyocyte uptake renders ${ }^{11} \mathrm{C}$-methionine as a very attractive tracer for imaging inflammation post-MI. Finally, PET imaging with ${ }^{68} \mathrm{Ga}-$ pentixafor targeting CXCR4, a protein involved in leukocyte recruitment to the injured region, has shown robust results in the infarcted myocardium in mice (Fig. 6) [139]. The use of this tracer in a small cohort of patients has shown more heterogeneous results, not providing any correlation between tracer uptake and any clinical predictive parameter. However, further larger and controlled cohort studies testing the usefulness of ${ }^{68} \mathrm{Ga}$-pentixafor imaging to determine outcome post-MI are required.

\section{Magnetic resonance spectroscopy}

Magnetic resonance spectroscopy (MRS) is the only technique that allows the evaluation of metabolites in the myocardium without the use of external contrast agents in vivo. MRS uses similar acquisition principles to MRI; however, it requires special broad band RF amplifiers and multinuclear $\mathrm{RF}$ coils to evaluate other atoms, apart from ${ }^{1} \mathrm{H}$ that also have magnetic moment such as ${ }^{31} \mathrm{P},{ }^{13} \mathrm{C},{ }^{23} \mathrm{Na}$, and ${ }^{87} \mathrm{Rb}$ [52]. The nuclei most investigated in human cardiac MRS is ${ }^{31} \mathrm{P}$,
A

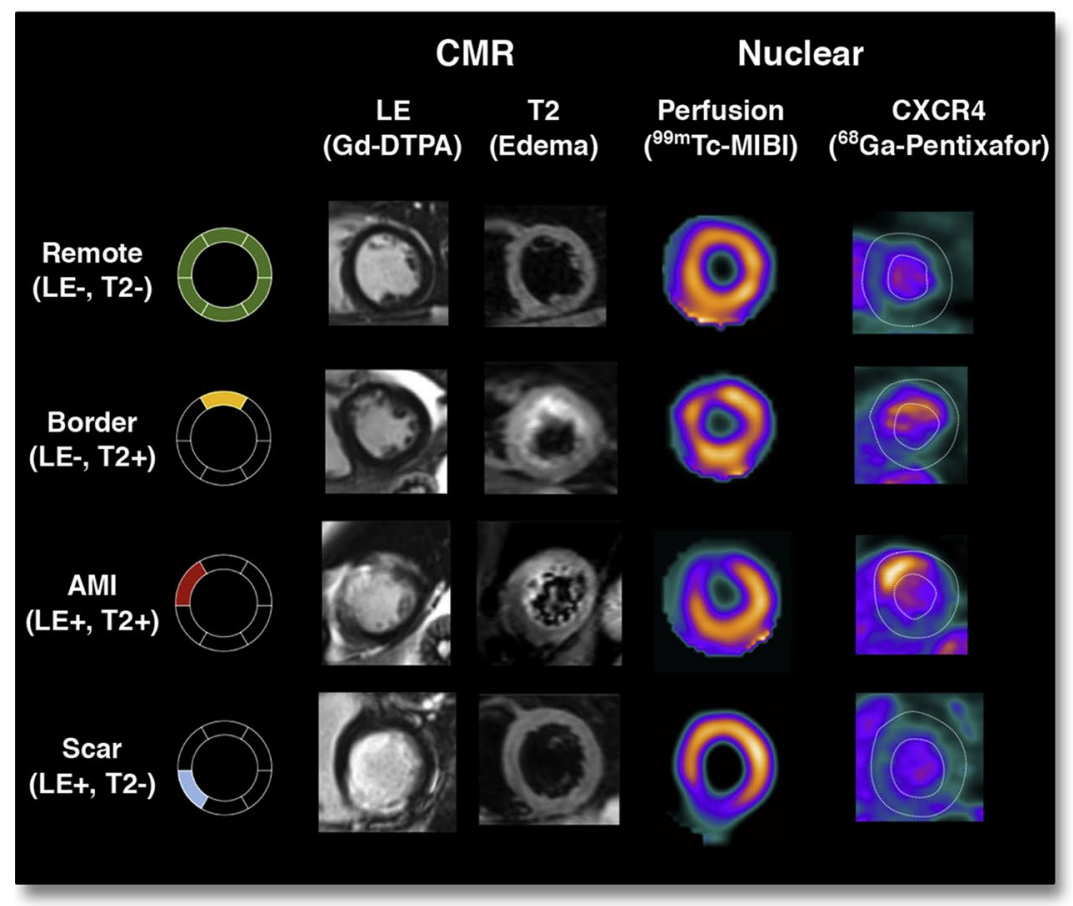

B

\section{CXCR4 Expression $\left({ }^{68} \mathrm{Ga}-P e n t i x a f o r\right.$ Uptake Score)}

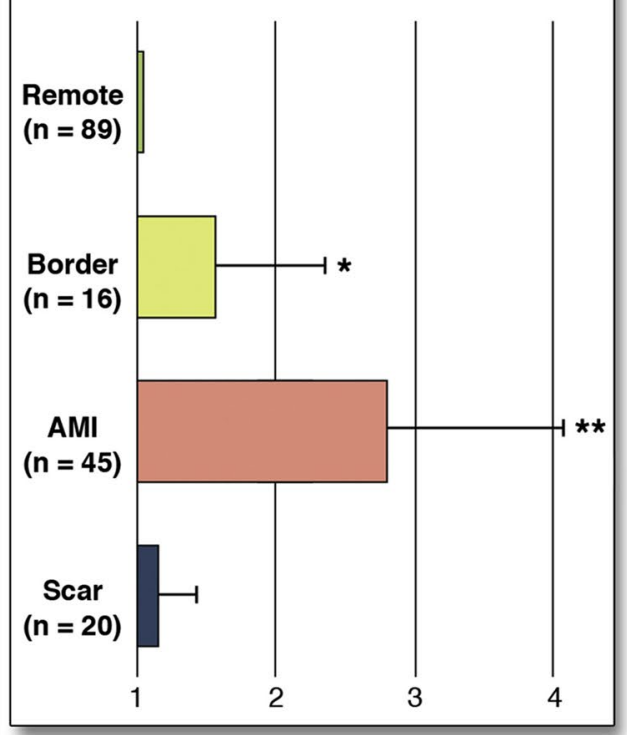

Fig. 6 Uptake of 68 Ga pentixafor in patients after acute ST-segment elevation myocardial infarction indicating various levels of CXCR4 expression in myocardial segments with different patterns of myocardial injury as defined by the presence (+) or absence (-) of gadolinium-diethylenetriamine pentaacetic acid (DTPA) late enhancement
(LE) or edema on T2-sequences (T2) at cardiac magnetic resonance imaging. a Representative short-axis slices characterizing four different types of segments. b Results of segmental pentixafor uptake score in respective segment types. ${ }^{*} p<0.05$ versus remote; $* * p<0.05$ versus all others. HLA horizontal long axis, $S A$ short axis [139] 


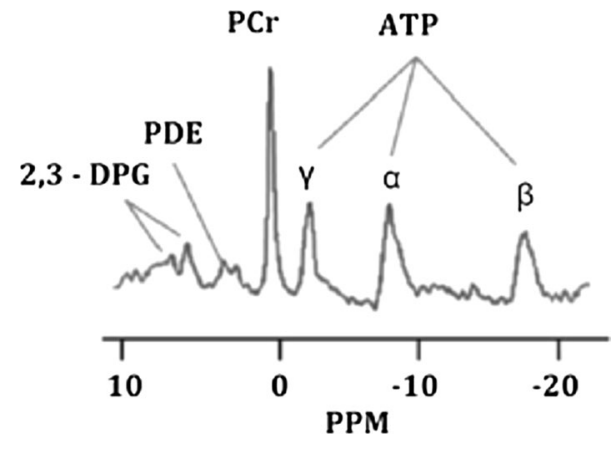

Fig. 7 Typical ${ }^{31} \mathrm{P}$-magnetic resonance spectroscopy spectrum showing 2,3-diphosphoglycerate (2,3-DGP), phosphodiester (PDE), phosphocreatine (PCr), and the three phosphorus peaks of ATP $(\gamma, \alpha$, and $\beta)$. The $x$-axis is expressed in parts per million (ppm) [108]

where a normal spectrum is composed by six phosphorus peaks including ATP (three peaks: $\gamma, \alpha$, and $\beta$ ), phosphocreatine (PCr), phosphodiesters (PDE), and 2,3-diphosphoglycerate (2,3-PDG) [108] (Fig. 7). From the ${ }^{31} \mathrm{P}$ spectrum, it is possible to calculate the PCr-to-ATP ratio which reflects the index of the energetic state of the heart [3]. In the context of ischemic heart disease, Weiss and collaborators demonstrated that in a cohort of 16 patients with coronary artery disease, during handgrip exercise, there was a transient imbalance between the oxygen supplied and required by the myocardium, which was reflected by a decreased ATP/ $\mathrm{PCr}$ ratio measured by ${ }^{31} \mathrm{P}-\mathrm{MRS}$ [153]. ATP/PCR ratio returned to normal after recovery. This transient effect was not detected in healthy volunteers and nonischemic patients [153]. In addition, several approaches to evaluate the efficacy of treatment interventions after ischemia have been tested [28]; however, large-scale trials to investigate longterm effects are needed.

${ }^{1} \mathrm{H}-\mathrm{MRS}$ is more widely available and has significantly more sensitivity and, therefore, more realistic potential than ${ }^{31} \mathrm{P}-\mathrm{MRS}$ to become a clinical tool. However, the information obtained using ${ }^{1} \mathrm{H}$-MRS differs from the information obtained by ${ }^{31} \mathrm{P}$-MRS. ${ }^{1} \mathrm{H}$-MRS allows the measurement of important metabolites such as creatine, lactate, carnitine, deoxymyoglobin, and cardiac lipids. The measurement of cardiac lipids provides information about the accumulation of triglycerides that are associated with impaired myocardial contractility [108]. ${ }^{23} \mathrm{Na}-\mathrm{MRS},{ }^{13} \mathrm{C}-\mathrm{MRS}$, and ${ }^{87} \mathrm{Rb}-\mathrm{MRS}$ have been very little explored, mainly due to their very low sensitivity; however, ${ }^{23} \mathrm{Na}$ signal has been correlated with acute necrosis and chronic myocardial scarring, therefore, a potential method to evaluate cardiac viability without the use of contrast agents [108]. ${ }^{13} \mathrm{C}$ has very limited application in the myocardium; however, some studies revealed the applicability of this spectrum to evaluate metabolites from the Kreb's cycle, $\beta$-oxidation of fatty acids and pyruvate flux. Finally, ${ }^{87} \mathrm{Rb}$ is an analogue of $\mathrm{K}^{+}$, so it is believed that this spectrum can provide valuable information about $\mathrm{Na}^{+} / \mathrm{K}^{+}$ATPase pumps [108]. One of the main advantages of MRS is the possible combination of the spectrums from different atoms that would provide a full characterisation of the myocardial state in coronary artery disease.

Cardiac MRS is a promising technique that could be used as a prognostic tool in the future. However, ${ }^{31} \mathrm{P}$-MRS is limited by its low spatial and temporal resolution and the low sensitivity of ${ }^{31} \mathrm{P}\left(6.6 \%\right.$ of ${ }^{1} \mathrm{H}$ sensitivity). Technological advances using higher field strengths $(>3 \mathrm{~T})$ have improved temporal and spatial resolutions and the signalto-noise; however, more advanced coil design, well-defined protocols, and sequence development are required to translate this method into clinical practice.

\section{Hybrid PET/MR imaging}

As we have stated throughout this review, both PET and MRI have been successfully in providing data for diagnosis, prognosis, and monitoring myocardial changes after myocardial infarction. Hybrid systems like PET/CT or SPECT/CT have already demonstrated their important clinical value. PET/ MRI systems have entered the market recently, and allow the acquisition of the PET data simultaneously or sequentially to MRI data. It has been presented as a possible alternative to PET/CT due to the lower radiation exposure and the improved cardiac and respiratory motion compensation. However, one of the common disadvantages of hybrid systems and in particular PET/MRI is the increased complexity of the workflow, due to the higher complexity of the MRI compared to CT. However, there are several advantages of using MRI compared to $\mathrm{CT}$, such as improved tissue characterization, tissue perfusion, diffusion, T1, T2, spectroscopic data, and motion estimation.

Myocardial tissue characterization is usually performed using ${ }^{18}$ F-FDG-PET. However, the myocardial uptake may be reduced in diabetic patients resulting in poor image quality together with the low spatial resolution of PET not being enough to assess the distribution of the tracer through the myocardium [113] (Fig. 8). LGE MRI after administration of a Gd-contrast agent is an alternative and has become the standard of reference for viability assessment $[68,69]$. There are only few small studies, where the feasibility of ${ }^{18}$ F-FDG-PET together with LGE MRI has been successfully tested [99]. Moreover, the use of ${ }^{18} \mathrm{~F}-\mathrm{NaF}-\mathrm{PET} / \mathrm{MRI}$ has been successfully validated this year to detect myocardial scar in a small cohort of STEMI patients [87]. Our group has recently developed a simultaneous CMRA-FDG-PET protocol, whereby respiratory motion is estimated from the CMRA acquisition and used to correct both the MR and PET attenuation and emission data [96]. These examples show the feasibility of PET/MRI to assess myocardial changes 
Fig. 8 Multimodal characterization of the myocardial tissue after AMI using PET/MRI.

Short-axis images of a patient who was imaged shortly after acute MI using simultaneous ${ }^{18} \mathrm{~F}-\mathrm{FDG}$ and ${ }^{13} \mathrm{~N}-\mathrm{NH}_{3}$ PET/ MRI. Myocardial scarring can be imaged using LGE MRI (left column, top; white arrows pointing at subendocardial non-transmural infarction). The area of myocardial infarction is exceeded by the myocardial oedema imaged using T2-weighted sequences (right column, top; red arrows). Using fasting-heparin ${ }^{18} \mathrm{~F}$-FDG-PET/ MRI, the area of post-ischemic inflammation or ischemic memory can be assessed. After revascularization by percutaneous coronary intervention (PCI), only a slightly reduced perfusion of the inferior wall was observed in this patient [113]

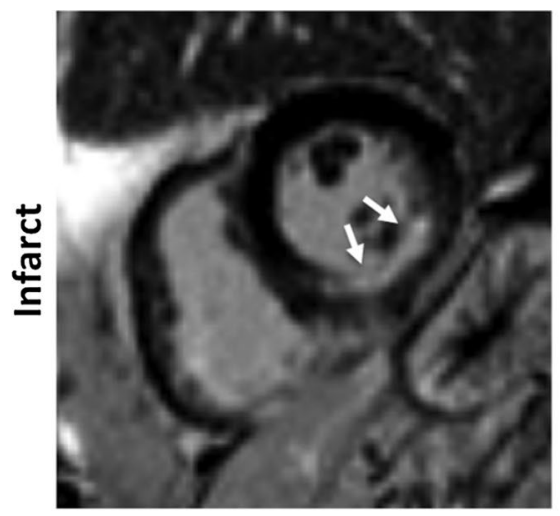

LGE

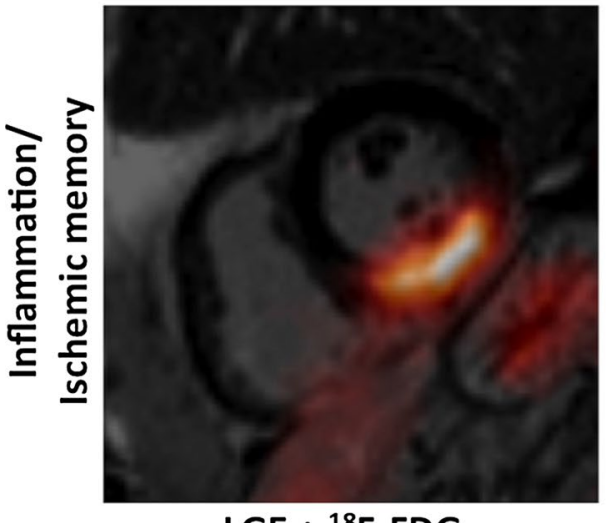

LGE $+{ }^{18}$ F-FDG

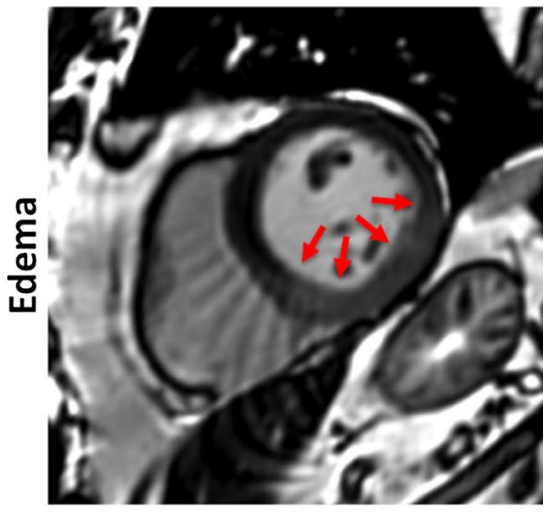

T2 weighted

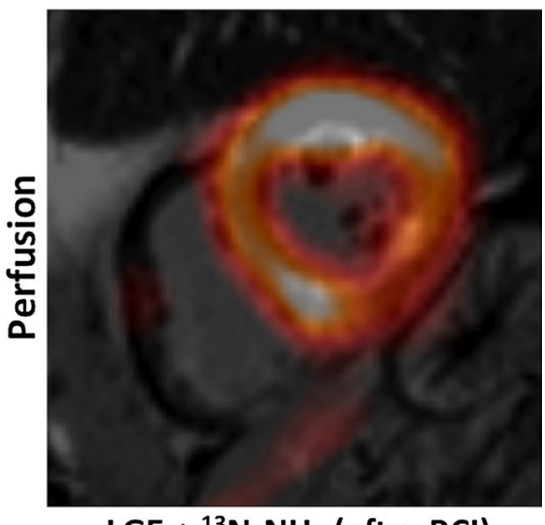

LGE $+{ }^{13} \mathrm{~N}-\mathrm{NH}_{3}$ (after PCl) after MI. However, this new technology is at the beginning of its development and technological advances and other challenges related to the complexity need to be evaluated. In addition, larger clinical validations in different pathologies are required to present $\mathrm{PET} / \mathrm{MRI}$ as a real clinical alternative.

\section{Diffusion tractography}

Diffusion MRI tractography and its use in cardiac imaging are an active area of research. Diffusion tractography has already been well described in imaging of the matter tracts of the central nervous system [76]. Tractography consists of imaging the direction of particular fibres of interest, producing a diffusion tensor (a vector made up of numerous eigenvalues) for each voxel within an image and this helps determine its direction. The computing system determines the main direction followed by various voxels and draws a pathway following the main direction of the diffusion tensor. Diffusion tractography can be useful in cardiac imaging to evaluate the architecture of the myofibers within the heart (Fig. 9). It has been shown that in healthy hearts, the myofibre architecture is smooth and constant, whereas in infarcted hearts, there is a severe disruption in the architecture [125, 129].

\section{Discussion}

Molecular cardiac imaging is a relatively new and exciting approach with a large scope for future work and improvements before its introduction into clinical practice. This review has focused on molecular imaging of post-MI cardiac remodelling which subsequently may lead to heart failure. These techniques allow visualisation of molecular pathways that occur during remodelling, allowing serial imaging showing disease progression and therapeutic response. Ultimately, this technology could be used by clinicians for prognostic purposes and for individual medication tailoring.

Although the current tracers have been successfully validated to image specific targets, they can always be improved. One of the chemical engineering challenges may be to achieve better sensitivity and stability of the current tracers and consequently superior images. Likewise, new tracers can be developed to broaden the library of tracers available, allowing the evaluation of different molecular pathways, and, therefore, increase our knowledge to provide a more personalised evaluation and treatment of patients. Some examples of possible targets that may have an important impact on cardiac imaging are $\mathrm{pH}$, tissue oxygenation, troponin, creatinine kinase, and specific cell populations such as inflammatory or reparative monocyte/macrophages. However, the tracers 
Fig. 9 Diffusion tractography in a healthy rat heart $(\mathbf{a}, \mathbf{b})$. Two infarcted rat hearts show severe distortion of myofibre architecture (c, d) [125, 129]
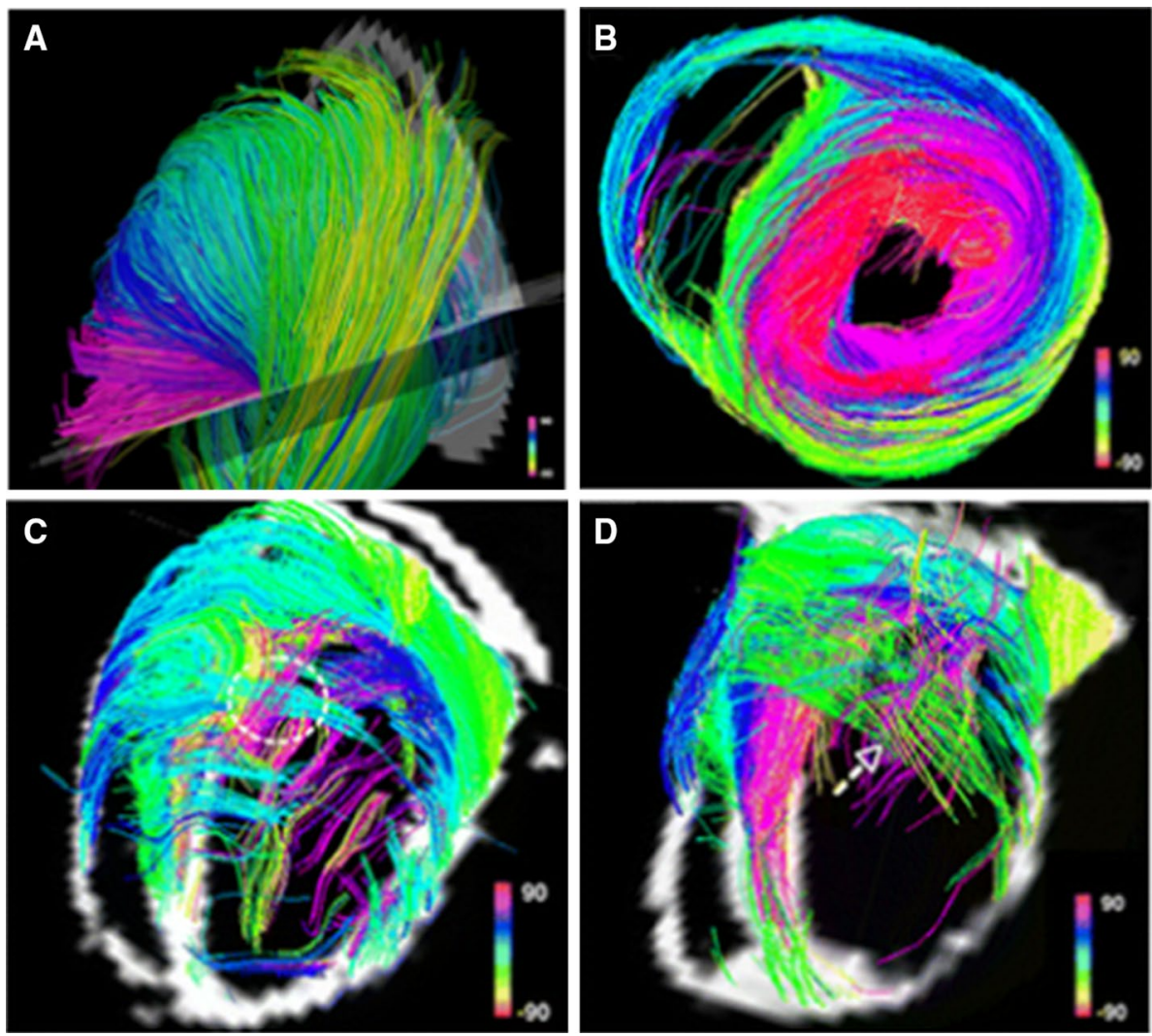

discussed are very specific to their target and have proven to be successful at visualising their targets, and perhaps, at this stage, we should focus on these tracers to pursue translation to clinical practice as opposed to researching new potential tracers.

There is extensive literature on how bringing this research into clinical practice is an expensive and time-consuming task [62, 83, 123]. Many of these studies have been conducted on mice and multiple authors have described the different behaviour of the tracers between mice, pigs, and humans, especially in patients with co-morbidities and more complex cellular mechanisms [12, 62]. However, recently, we have seen human trials in many of the imaging techniques described. Although initial pilot studies, they have so far shown tracers to be safe in humans and to successfully visualise their targets. Clearly, more human studies are required to evaluate the safety and viability of these tracers, but translating this new technology into clinical practice is becoming more realistic than first thought. Once these tracers have been deemed safe for use in humans, large multicentre clinical trials will be required to ensure they can successfully image their targets, provide prognostic information to patients and offer evidence to clinicians to individually tailor medication to the patient. Imaging techniques will only be considered for clinical practice if they are deemed safe, robust and have a clinically relevant outcome that will aid or change the management of a patient. We are confident that these techniques will make it to the bedside in the future and will enable clinicians to monitor disease progression and therapeutic response.

Furthermore, these techniques could be used as an adjunct to novel molecular therapeutics. Anti-inflammatory and proangiogenic or other molecular therapies have recently been studied [5, 65, 111]. The imaging techniques described in this review can act as guidance for these therapies both in experimental studies and clinically if these therapies make it to the bedside.

Efficient healthcare spending is vitally important in today's climate and the question of cost-efficiency of this new technology must be asked. However, as imaging systems become more advanced and scan acquisition times decrease so does the price of running a single scan, and given the significant cost of heart failure on healthcare systems if these techniques contribute to a decrease in morbidity and mortality then perhaps overall spending would be reduced. Naturally, as imaging systems continue to improve so will the imaging techniques described in this review. As PET/MRI hybrid systems are a recent addition to the market, this will also become an active area of research in this field as these two individual modalities make up the majority of this field.

This field is in an exciting phase, given the recent human trials. Further evaluation and clinical trials need to be implemented. Ultimately, more work needs to be done in this area 
before molecular cardiac imaging becomes part of the clinician's toolbox; however, large steps have been taken recently and clinical translation is becoming ever more promising.

\section{Conclusion}

The main clinical experience with cardiac molecular imaging is with nuclear imaging due to the availability of tracers, their high sensitivity, and low risk. New molecular imaging techniques have been proposed and studied within both nuclear imaging and MRI. SPECT, PET, and MRI have the ability to image different cardiac processes, providing an extensive, non-invasive examination of the infarct process, and subsequent healing. Early human trials have shown promising results, and while significant challenges remain, these advances have shown potential advantages and may lead to improved, more individualised patient management. Large, multi-centre clinical trials are needed for safety evaluation of tracers in addition to diagnostic and prognostic value confirmation.

Acknowledgements The authors acknowledge financial support from: (1) EPSRC (EP/P001009/1 and EP/P007619/1), (2) the British Heart Foundation (RG/12/1/29262), (3) FONDECYT no. 1161051, (4) the Centre of Excellence in Medical Engineering funded by the Wellcome Trust and EPSRC (203148/Z/16/Z), and (5) the Department of Health via the National Institute for Health Research (NIHR) comprehensive Biomedical Research Centre award to Guy's and St Thomas' NHS Foundation Trust in partnership with King's College London and King's College Hospital NHS Foundation Trust. The views expressed are those of the authors and not necessarily those of the NHS, the NIHR or the Department of Health.

Open Access This article is distributed under the terms of the Creative Commons Attribution 4.0 International License (http://creativecomm ons.org/licenses/by/4.0/), which permits unrestricted use, distribution, and reproduction in any medium, provided you give appropriate credit to the original author(s) and the source, provide a link to the Creative Commons license, and indicate if changes were made.

\section{References}

1. Abubakar I, Tillmann T, Banerjee A (2015) Global, regional, and national age-sex specific all-cause and cause-specific mortality for 240 causes of death, 1990-2013: a systematic analysis for the Global Burden of Disease Study 2013. Lancet 385:117-171. http s://doi.org/10.1016/S0140-6736(14)61682-2

2. Ahmadi A, Ohira H, Mielniczuk LM (2015) FDG PET imaging for identifying pulmonary hypertension and right heart failure. Curr Cardiol Rep 17:555. https://doi.org/10.1007/s11886-0140555-7

3. Akki A, Gupta A, Weiss RG (2013) Magnetic resonance imaging and spectroscopy of the murine cardiovascular system. Am J Physiol Heart Circ Physiol 304:H633-H648. https://doi. org/10.1152/ajpheart.00771.2011

4. Asano Y, Ihn H, Yamane K, Jinnin M, Mimura Y, Tamaki K (2005) Increased expression of integrin alpha(v)beta3 contributes to the establishment of autocrine TGF-beta signaling in scleroderma fibroblasts. J Immunol 175:7708-7718. https://doi.org/10.4049/jimmunol.175.11.7708

5. Atluri P, Woo YJ (2008) Pro-angiogenic cytokines as cardiovascular therapeutics. BioDrugs 22:209-222. https://doi. org/10.2165/00063030-200822040-00001

6. Avkiran M (2003) Basic biology and pharmacology of the cardiac sarcolemmal sodium/hydrogen exchanger. J Card Surg 18:3-12. https://doi.org/10.1046/j.1540-8191.18.s1.2.x

7. Baines CP (2009) The mitochondrial permeability transition pore and ischemia-reperfusion injury. Basic Res Cardiol 104:181-188. https://doi.org/10.1007/s00395-009-0004-8

8. Braunwald E, Kloner RA (1985) Myocardial reperfusion: a double-edged sword? J Clin Investig 76:1713-1719. https:// doi.org/10.1172/JCI112160

9. Cai K, Caruthers SD, Huang W, Williams TA, Zhang H, Wickline SA, Lanza GM, Winter PM (2010) MR molecular imaging of aortic angiogenesis. JACC Cardiovasc Imaging 3:824-832. https://doi.org/10.1016/j.jcmg.2010.03.012

10. Cai M, Ren L, Yin X, Guo Z, Li Y, He T, Tang Y, Long T, Liu $Y$, Liu G (2016) PET monitoring angiogenesis of infarcted myocardium after treatment with vascular endothelial growth factor and bone marrow mesenchymal stem cells. Amino Acids 48:811. https://doi.org/10.1007/s00726-015-2129-4

11. Caravan P, Das B, Dumas S, Epstein FH, Helm PA, Jacques V, Koerner S, Kolodziej A, Shen L, Sun W (2007) Collagentargeted MRI contrast agent for molecular imaging of fibrosis. Angew Chem Int Ed 46:8171-8173. https://doi.org/10.1002/ anie. 200700700

12. Chen IY, Wu JC (2011) Cardiovascular molecular imaging: focus on clinical translation. Circulation 123:425-443. https:// doi.org/10.1161/CIRCULATIONAHA.109.916338

13. Chiong M, Wang ZV, Pedrozo Z, Cao DJ, Troncoso R, Ibacache M, Criollo A, Nemchenko A, Hill JA, Lavandero S (2011) Cardiomyocyte death: mechanisms and translational implications. Cell Death Dis 2:e244. https://doi.org/10.1038/cddis.2011.130

14. Choi KM, Kim RJ, Gubernikoff G, Vargas JD, Parker M, Judd RM (2001) Transmural extent of acute myocardial infarction predicts long-term improvement in contractile function. Circulation 104:1101-1107. https://doi.org/10.1161/hc3501.096798

15. Civitarese RA, Kapus A, McCulloch CA, Connelly KA (2017) Role of integrins in mediating cardiac fibroblast-cardiomyocyte cross talk: a dynamic relationship in cardiac biology and pathophysiology. Basic Res Cardiol 112:6. https://doi. org/10.1007/s00395-016-0598-6

16. Creemers EE, Davis JN, Parkhurst AM, Leenders P, Dowdy KB, Hapke E, Hauet AM, Escobar PG, Cleutjens JP, Smits JF, Daemen MJ, Zile MR, Spinale FG (2003) Deficiency of TIMP-1 exacerbates LV remodeling after myocardial infarction in mice. Am J Physiol Heart Circ Physiol 284:H364-H371. https://doi.org/10.1152/ajpheart.00511.2002

17. Danielsen CC, Wiggers H, Andersen HR (1998) Increased amounts of collagenase and gelatinase in porcine myocardium following ischemia and reperfusion. J Mol Cell Cardiol 30:1431-1442. https://doi.org/10.1006/jmcc.1998.0711

18. DeWood MA, Spores J, Notske R, Mouser LT, Burroughs R, Golden MS, Lang HT (1980) Prevalence of total coronary occlusion during the early hours of transmural myocardial infarction. N Engl J Med 303:897-902. https://doi.org/10.1056 /NEJM198010163031601

19. Dilsizian V, Zynda TK, Petrov A, Ohshima S, Tahara N, Haider N, Donohue A, Aras O, Femia FJ, Hillier SM (2012) Molecular imaging of human ACE-1 expression in transgenic rats. JACC Cardiovasc Imaging 5:409-418. https://doi.org/10.1016/j.jcmg 2011.10.008 
20. Dilsizian V, Eckelman WC, Loredo ML, Jagoda EM, Shirani $\mathrm{J}$ (2007) Evidence for tissue angiotensin-converting enzyme in explanted hearts of ischemic cardiomyopathy using targeted radiotracer technique. J Nucl Med 48:182-187

21. Dimastromatteo J, Riou LM, Ahmadi M, Pons G, Pellegrini E, Broisat A, Sancey L, Gavrilina T, Boturyn D, Dumy P (2010) In vivo molecular imaging of myocardial angiogenesis using the $\alpha v \beta 3$ integrin-targeted tracer 99mTc-RAFT-RGD. J Nucl Cardiol 17:435-443. https://doi.org/10.1007/s12350-010-9191-9

22. Drake CJ, Cheresh DA, Little CD (1995) An antagonist of integrin alpha $v$ beta 3 prevents maturation of blood vessels during embryonic neovascularization. J Cell Sci 108(Pt 7):2655-2661

23. Eitel I, Desch S, Fuernau G, Hildebrand L, Gutberlet M, Schuler G, Thiele H (2010) Prognostic significance and determinants of myocardial salvage assessed by cardiovascular magnetic resonance in acute reperfused myocardial infarction. J Am Coll Cardiol 55:2470-2479. https://doi.org/10.1016/j.jacc.2010.01.049

24. Femia F, Maresca K, Joyal J, Barrett J, Coleman T, Aras O, Messina S, Eckelman W, Dilsizian V, Babich J (2006) Synthesis and evaluation of radioligands for angiotensin converting enzyme (ACE) imaging. J Nucl Med 47:260P

25. Femia FJ, Maresca KP, Hillier SM, Zimmerman CN, Joyal JL, Barrett JA, Aras O, Dilsizian V, Eckelman WC, Babich JW (2008) Synthesis and evaluation of a series of $99 \mathrm{mTc}(\mathrm{CO}) 3+$ lisinopril complexes for in vivo imaging of angiotensin-converting enzyme expression. J Nucl Med 49:970-977. https://doi. org/10.2967/jnumed.107.049064

26. Flogel U, Ding Z, Hardung H, Jander S, Reichmann G, Jacoby C, Schubert R, Schrader J (2008) In vivo monitoring of inflammation after cardiac and cerebral ischemia by fluorine magnetic resonance imaging. Circulation 118:140-148. https://doi. org/10.1161/CIRCULATIONAHA.107.737890

27. Fox K, Garcia MA, Ardissino D, Buszman P, Camici PG, Crea F, Daly C, De Backer G, Hjemdahl P, Lopez-Sendon J, Marco J, Morais J, Pepper J, Sechtem U, Simoons M, Thygesen K, Priori SG, Blanc JJ, Budaj A, Camm J, Dean V, Deckers J, Dickstein K, Lekakis J, McGregor K, Metra M, Morais J, Osterspey A, Tamargo J, Zamorano JL, Task Force on the Management of Stable Angina Pectoris of the European Society of Cardiology, ESC Committee for Practice Guidelines (CPG) (2006) Guidelines on the management of stable angina pectoris: executive summary: The Task Force on the Management of Stable Angina Pectoris of the European Society of Cardiology. Eur Heart J 27:1341-1381. https://doi.org/10.1093/eurheartj/eh1001

28. Fragasso G, Perseghin G, De Cobelli F, Esposito A, Palloshi A, Lattuada G, Scifo P, Calori G, Del Maschio A, Margonato A (2006) Effects of metabolic modulation by trimetazidine on left ventricular function and phosphocreatine/adenosine triphosphate ratio in patients with heart failure. Eur Heart J. https://doi. org/10.1093/eurheartj/ehi816

29. Frangogiannis NG (2006) The mechanistic basis of infarct healing. Antioxid Redox Signal 8:1907-1939. https://doi.org/10.1089 /ars.2006.8.1907

30. Friedrich MG, Abdel-Aty H, Taylor A, Schulz-Menger J, Messroghli D, Dietz R (2008) The salvaged area at risk in reperfused acute myocardial infarction as visualized by cardiovascular magnetic resonance. J Am Coll Cardiol 51:1581-1587. https://doi. org/10.1016/j.jacc.2008.01.019

31. Fukushima K, Bravo PE, Higuchi T, Schuleri KH, Lin X, Abraham MR, Xia J, Mathews WB, Dannals RF, Lardo AC (2012) Molecular hybrid positron emission tomography/computed tomography imaging of cardiac angiotensin II type 1 receptors. J Am Coll Cardiol 60:2527-2534. https://doi.org/10.1016/j.jacc 2012.09.023

32. Gao H, Lang L, Guo N, Cao F, Quan Q, Hu S, Kiesewetter DO, Niu G, Chen X (2012) PET imaging of angiogenesis after myocardial infarction/reperfusion using a one-step labeled integrin-targeted tracer 18 F-AlF-NOTA-PRGD2. Eur J Nucl Med Mol Imaging 39:683-692. https://doi.org/10.1007/s002 59-011-2052-1

33. Gedik N, Thielmann M, Kottenberg E, Peters J, Jakob H, Heusch G, Kleinbongard P (2014) No evidence for activated autophagy in left ventricular myocardium at early reperfusion with protection by remote ischemic preconditioning in patients undergoing coronary artery bypass grafting. PLoS One 9:e96567. https://doi.org/10.1371/journal.pone.0096567

34. Ghosh N, Rimoldi OE, Beanlands RS, Camici PG (2010) Assessment of myocardial ischaemia and viability: role of positron emission tomography. Eur Heart J 31:2984-2995. https://doi.org/10.1093/eurheartj/ehq361

35. Hamill TG, Burns HD, Dannals RF, Mathews WB, Musachio JL, Ravert HT, Naylor EM (1996) Development of [11C] L-159,884: a radiolabelled, nonpeptide angiotensin II antagonist that is useful for angiotensin II, AT1 receptor imaging. Appl Radiat Isot 47:211-218. https://doi.org/10.1016/0969 -8043(95)00273-1

36. Han J, Zou C, Mei L, Zhang Y, Qian Y, You S, Pan Y, Xu Z, Bai B, Huang W (2017) MD2 mediates angiotensin II-induced cardiac inflammation and remodeling via directly binding to Ang II and activating TLR4/NF- $\kappa$ B signaling pathway. Basic Res Cardiol 112:9. https://doi.org/10.1007/s00395-016-0599-5

37. Harris TD, Kalogeropoulos S, Nguyen T, Liu S, Bartis J, Ellars C, Edwards S, Onthank D, Silva P, Yalamanchili P (2003) Design, synthesis, and evaluation of radiolabeled integrin $\alpha \mathrm{v} \beta 3$ receptor antagonists for tumor imaging and radiotherapy. Cancer Biother Radiopharm 18:627-641. https://doi.org/10.1089/1084 97803322287727

38. Haubner R, Kuhnast B, Mang C, Weber WA, Kessler H, Wester H, Schwaiger M (2004) [18F] Galacto-RGD: synthesis, radiolabeling, metabolic stability, and radiation dose estimates. Bioconjug Chem 15:61-69. https://doi.org/10.1021/bc034170n

39. Haubner R, Wester HJ, Burkhart F, Senekowitsch-Schmidtke R, Weber W, Goodman SL, Kessler H, Schwaiger M (2001) Glycosylated RGD-containing peptides: tracer for tumor targeting and angiogenesis imaging with improved biokinetics. J Nucl Med 42:326-336

40. Hausenloy DJ, Barrabes JA, Bøtker HE, Davidson SM, Di Lisa F, Downey J, Engstrom T, Ferdinandy P, Carbrera-Fuentes HA (2016) Heusch G (2016) Ischaemic conditioning and targeting reperfusion injury: a 30 year voyage of discovery. Basic Res Cardiol 111:70. https://doi.org/10.1007/s00395-016-0588-8

41. Helm PA, Caravan P, French BA, Jacques V, Shen L, Xu Y, Beyers RJ, Roy RJ, Kramer CM, Epstein FH (2008) Postinfarction myocardial scarring in mice: molecular MR imaging with use of a collagen-targeting contrast agent 1. Radiology 247:788-796. https://doi.org/10.1148/radiol.2473070975

42. Heusch $\mathrm{G}$ (2008) Heart rate in the pathophysiology of coronary blood flow and myocardial ischaemia: benefit from selective bradycardic agents. Br J Pharmacol 153:1589-1601. https://doi. org/10.1038/sj.bjp.0707673

43. Heusch G, Gersh BJ (2016) The pathophysiology of acute myocardial infarction and strategies of protection beyond reperfusion: a continual challenge. Eur Heart J 38:774-784. https://doi. org/10.1093/eurheartj/ehw224

44. Heusch G, Libby P, Gersh B, Yellon D, Böhm M, Lopaschuk G, Opie L (2014) Cardiovascular remodelling in coronary artery disease and heart failure. Lancet 383:1933-1943. https://doi. org/10.1016/S0140-6736(14)60107-0

45. Heusch G, Boengler K, Schulz R (2010) Inhibition of mitochondrial permeability transition pore opening: the holy grail of cardioprotection. Basic Res Cardiol 105:151-154. https://doi. org/10.1007/s00395-009-0080-9 
46. Heusch P, Nensa F, Heusch G (2015) Is MRI really the gold standard for the quantification of salvage from myocardial infarction? Circ Res 117:222-224. https://doi.org/10.1161/CIRCRESA HA.117.306929

47. Higgins CB, Herfkens R, Lipton MJ, Sievers R, Sheldon P, Kaufman L, Crooks LE (1983) Nuclear magnetic resonance imaging of acute myocardial infarction in dogs: alterations in magnetic relaxation times. Am J Cardiol 52:184-188. https:// doi.org/10.1016/0002-9149(83)90093-0

48. Higuchi T, Fukushima K, Xia J, Mathews WB, Lautamaki R, Bravo PE, Javadi MS, Dannals RF, Szabo Z, Bengel FM (2010) Radionuclide imaging of angiotensin II type 1 receptor upregulation after myocardial ischemia-reperfusion injury. J Nucl Med 51:1956-1961. https://doi.org/10.2967/jnumed.110.079855

49. Higuchi T, Bengel FM, Seidl S, Watzlowik P, Kessler H, Hegenloh R, Reder S, Nekolla SG, Wester HJ, Schwaiger M (2008) Assessment of alphavbeta3 integrin expression after myocardial infarction by positron emission tomography. Cardiovasc Res 78:395-403. https://doi.org/10.1093/cvr/cvn033

50. Hinz B (2006) Masters and servants of the force: the role of matrix adhesions in myofibroblast force perception and transmission. Eur J Cell Biol 85:175-181. https://doi.org/10.1016/j.ejcb .2005.09.004

51. Hofstra L, Liem H, Dumont EA, Boersma HH, van Heerde WL, Doevendans PA, DeMuinck E, Wellens H, Kemerink GJ, Reutelingsperger CP (2000) Visualisation of cell death in vivo in patients with acute myocardial infarction. Lancet 356:209-212. https://doi.org/10.1016/S0140-6736(00)02482-X

52. Hudsmith LE, Neubauer S (2009) Magnetic resonance spectroscopy in myocardial disease. JACC Cardiovasc Imaging 2:87-96. https://doi.org/10.1016/j.jcmg.2008.08.005

53. Hwang DR, Eckelman WC, Mathias CJ, Petrillo EW Jr, Lloyd J, Welch MJ (1991) Positron-labeled angiotensin-converting enzyme (ACE) inhibitor: fluorine-18-fluorocaptopril. Probing the ACE activity in vivo by positron emission tomography. $\mathrm{J}$ Nucl Med 32:1730-1737

54. Ibáñez B, Heusch G, Ovize M, Van de Werf F (2015) Evolving therapies for myocardial ischemia/reperfusion injury. J Am Coll Cardiol 65:1454-1471. https://doi.org/10.1016/j.jacc.2015 .02 .032

55. Inserte J, Cardona M, Poncelas-Nozal M, Hernando V, Vilardosa Ú, Aluja D, Parra VM, Sanchis D, Garcia-Dorado D (2016) Studies on the role of apoptosis after transient myocardial ischemia: genetic deletion of the executioner caspases- 3 and- 7 does not limit infarct size and ventricular remodeling. Basic Res Cardiol 111:18. https://doi.org/10.1007/s00395-016-0537-6

56. Inserte J, Hernando V, Garcia-Dorado D (2012) Contribution of calpains to myocardial ischaemia/reperfusion injury. Cardiovasc Res 96:23-31. https://doi.org/10.1093/cvr/cvs232

57. Ishimaru S, Tsujino I, Takei T, Tsukamoto E, Sakaue S, Kamigaki M, Ito N, Ohira H, Ikeda D, Tamaki N (2005) Focal uptake on $18 \mathrm{~F}$-fluoro-2-deoxyglucose positron emission tomography images indicates cardiac involvement of sarcoidosis. Eur Heart J 26:1538-1543. https://doi.org/10.1093/eurheartj/ehi180

58. Jaarsma C, Nagel E, Schalla S (2013) A critical review of different imaging methods for the assessment of myocardial ischemia. Curr Cardiovasc Imaging Rep 6:117-127. https://doi.org/10.1007 /s12410-012-9185-x

59. Jaarsma C, Leiner T, Bekkers SC, Crijns HJ, Wildberger JE, Nagel E, Nelemans PJ, Schalla S (2012) Diagnostic performance of noninvasive myocardial perfusion imaging using single-photon emission computed tomography, cardiac magnetic resonance, and positron emission tomography imaging for the detection of obstructive coronary artery disease: a meta-analysis. J Am Coll Cardiol 59:1719-1728. https://doi.org/10.1016/j.jacc.2011 .12 .040
60. Jennings RB (2013) Historical perspective on the pathology of myocardial ischemia/reperfusion injury. Circ Res 113:428-438. https://doi.org/10.1161/CIRCRESAHA.113.300987

61. Jennings RB, Murry CE, Steenbergen C Jr, Reimer KA (1990) Development of cell injury in sustained acute ischemia. Circulation 82:II2-II12

62. Jivraj N, Phinikaridou A, Shah AM, Botnar RM (2014) Molecular imaging of myocardial infarction. Basic Res Cardiol 109:116. https://doi.org/10.1007/s00395-013-0397-2

63. Jung M, Ma Y, Iyer RP, DeLeon-Pennell KY, Yabluchanskiy A, Garrett MR, Lindsey ML (2017) IL-10 improves cardiac remodeling after myocardial infarction by stimulating M2 macrophage polarization and fibroblast activation. Basic Res Cardiol 112:33. https://doi.org/10.1007/s00395-017-0622-5

64. Kajstura J, Cheng W, Reiss K, Clark WA, Sonnenblick EH, Krajewski S, Reed JC, Olivetti G, Anversa P (1996) Apoptotic and necrotic myocyte cell deaths are independent contributing variables of infarct size in rats. Lab Investig 74:86-107

65. Khan R, Spagnoli V, Tardif J, L'Allier PL (2015) Novel antiinflammatory therapies for the treatment of atherosclerosis. Atherosclerosis 240:497-509. https://doi.org/10.1016/j.atherosclero sis.2015.04.783

66. Kietselaer BL, Reutelingsperger CP, Boersma HH, Heidendal GA, Liem IH, Crijns HJ, Narula J, Hofstra L (2007) Noninvasive detection of programmed cell loss with $99 \mathrm{mTc}$-labeled annexin A5 in heart failure. J Nucl Med 48:562-567. https://doi. org/10.2967/jnumed.106.039453

67. Kingery JR, Hamid T, Lewis RK, Ismahil MA, Bansal SS, Rokosh G, Townes TM, Ildstad ST, Jones SP, Prabhu SD (2017) Leukocyte iNOS is required for inflammation and pathological remodeling in ischemic heart failure. Basic Res Cardiol 112:19. https://doi.org/10.1007/s00395-017-0609-2

68. Klein C, Schmal TR, Nekolla SG, Schnackenburg B, Fleck E, Nagel E (2007) Mechanism of late gadolinium enhancement in patients with acute myocardial infarction. J Cardiovasc Magn Reson 9:653-658. https://doi.org/10.1080/10976640601105614

69. Klein C, Nekolla SG, Balbach T, Schnackenburg B, Nagel E, Fleck E, Schwaiger M (2004) The influence of myocardial blood flow and volume of distribution on late Gd-DTPA kinetics in ischemic heart failure. J Magn Reson Imaging 20:588-594. http s://doi.org/10.1002/jmri.20164

70. Klein JL, Garcia EV, DePuey EG, Campbell J, Taylor AT, Pettigrew RI, D'Amato P, Folks R, Alazraki N (1990) Reversibility bull's-eye: a new polar bull's-eye map to quantify reversibility of stress-induced SPECT thallium-201 myocardial perfusion defects. J Nucl Med 31:1240-1246

71. Kleinbongard P, Schulz R, Heusch G (2011) TNF $\alpha$ in myocardial ischemia/reperfusion, remodeling and heart failure. Heart Fail Rev 16:49-69. https://doi.org/10.1007/s10741-010-9180-8

72. Krijnen PA, Nijmeijer R, Meijer CJ, Visser CA, Hack CE, Niessen HW (2002) Apoptosis in myocardial ischaemia and infarction. J Clin Pathol 55:801-811. https://doi.org/10.1136/ jcp.55.11.801

73. Ladilov YV, Siegmund B, Piper HM (1995) Protection of reoxygenated cardiomyocytes against hypercontracture by inhibition of $\mathrm{Na}^{+} / \mathrm{H}^{+}$exchange. Am J Physiol 268:H1531-H1539

74. Laitinen I, Notni J, Pohle K, Rudelius M, Farrell E, Nekolla SG, Henriksen G, Neubauer S, Kessler H, Wester H (2013) Comparison of cyclic RGD peptides for $\alpha$ v $\beta 3$ integrin detection in a rat model of myocardial infarction. EJNMMI research 3:38. https:// doi.org/10.1186/2191-219X-3-38

75. Lassen TR, Nielsen JM, Johnsen J, Ringgaard S, Bøtker HE, Kristiansen SB (2017) Effect of paroxetine on left ventricular remodeling in an in vivo rat model of myocardial infarction. Basic Res Cardiol 112:26. https://doi.org/10.1007/s00395-0170614-5 
76. Lazar M (2010) Mapping brain anatomical connectivity using white matter tractography. NMR Biomed 23:821-835. https:// doi.org/10.1002/nbm.1579

77. Lee SH, Jung YS, Lee BH, Yun SI, Yoo SE, Shin HS (1999) Characterization of angiotensin II antagonism displayed by SK-1080, a novel nonpeptide AT1-receptor antagonist. J Cardiovasc Pharmacol 33:367-374

78. Lee WW, Marinelli B, van der Laan Anja M, Sena BF, Gorbatov R, Leuschner F, Dutta P, Iwamoto Y, Ueno T, Begieneman MP (2012) PET/MRI of inflammation in myocardial infarction. J Am Coll Cardiol 59:153-163. https://doi.org/10.1016/j.jacc .2011 .08 .066

79. Lee YC, Kiesewetter DO, Lang L, Jagoda EM, Shirani J, Dilsizian V, Eckelman WC (2001) Synthesis of 4-[18F] fluorobenzoyllisinopril: A radioligand for angiotensin converting enzyme (ACE) imaging with positron emission tomography. J Label Compd. https://doi.org/10.1002/jlcr.2580440194

80. Links JM, Jeremy RW, Dyer SM, Frank TL, Becker LC (1990) Wiener filtering improves quantification of regional myocardial perfusion with thallium-201 SPECT. J Nucl Med 31:1230-1236

81. Lu E, Wagner WR, Schellenberger U, Abraham JA, Klibanov AL, Woulfe SR, Csikari MM, Fischer D, Schreiner GF, Brandenburger GH, Villanueva FS (2003) Targeted in vivo labeling of receptors for vascular endothelial growth factor: approach to identification of ischemic tissue. Circulation 108:97-103. https://doi.org/10.1161/01.CIR.0000079100.3817 6.83

82. Maeng M, Mortensen UM, Kristensen J, Kristiansen SB, Andersen HR (2006) Hypothermia during reperfusion does not reduce myocardial infarct size in pigs. Basic Res Cardiol 101:61-68. https://doi.org/10.1007/s00395-005-0550-7

83. Majmudar MD, Nahrendorf M (2012) Cardiovascular molecular imaging: the road ahead. J Nucl Med 53:673-676. https://doi. org/10.2967/jnumed.111.099838

84. Makowski MR, Ebersberger U, Nekolla S, Schwaiger M (2008) In vivo molecular imaging of angiogenesis, targeting alphavbeta3 integrin expression, in a patient after acute myocardial infarction. Eur Heart J 29:2201. https://doi.org/10.1093/eurheartj/ehn129

85. Mann DL (2002) Inflammatory mediators and the failing heart: past, present, and the foreseeable future. Circ Res 91:988-998. https://doi.org/10.1161/01.RES.0000043825.01705.1B

86. Mansfield P, Maudsley AA (1977) Medical imaging by NMR. Br J Radiol 50:188-194. https://doi.org/10.1259/0007-1285 $-50-591-188$

87. Marchesseau S, Seneviratna A, Sjöholm AT, Qin DL, Ho JX, Hausenloy DJ, Townsend DW, Richards AM, Totman JJ, Chan MY (2017) Hybrid PET/CT and PET/MRI imaging of vulnerable coronary plaque and myocardial scar tissue in acute myocardial infarction. J Nucl Cardiol. https://doi.org/10.1007/s12350-0170918-8

88. Matarrese M, Salimbeni A, Turolla EA, Turozzi D, Moresco RM, Poma D, Magni F, Todde S, Rossetti C, Sciarrone MT (2004) $11 \mathrm{C}$-Radiosynthesis and preliminary human evaluation of the disposition of the ACE inhibitor [11 C] zofenoprilat. Bioorg Med Chem 12:603-611. https://doi.org/10.1016/j.bmc.2003.10.054

89. Mathews WB, Yoo S, Lee S, Scheffel U, Rauseo PA, Zober TG, Gocco G, Sandberg K, Ravert HT, Dannals RF (2004) A novel radioligand for imaging the AT 1 angiotensin receptor with PET. Nucl Med Biol 31:571-574. https://doi.org/10.1016/j.nucmedbi o.2003.10.014

90. Mathews WB, Burns HD, Dannals RF, Ravert HT, Naylor EM (1995) Carbon-11 labeling of a potent, nonpeptide, at 1-selective angiotensin-II receptor antagonist: MK-996. J Label Compd Radiopharm 36:729-737. https://doi.org/10.1002/jlcr.25803608 04
91. Matthaei D, Haase A, Henrich D, Duhmke E (1990) Cardiac and vascular imaging with an MR snapshot technique. Radiology 177:527-532. https://doi.org/10.1148/radiolog y.177.2.2217796

92. McMurray JJ, Pfeffer MA (2005) Heart failure. Lancet 365:1877_ 1889. https://doi.org/10.1016/s0140-6736(05)66621-4

93. Meoli DF, Sadeghi MM, Krassilnikova S, Bourke BN, Giordano FJ, Dione DP, Su H, Edwards DS, Liu S, Harris TD, Madri JA, Zaret BL, Sinusas AJ (2004) Noninvasive imaging of myocardial angiogenesis following experimental myocardial infarction. J Clin Investig 113:1684-1691. https://doi.org/10.1172/JCI20352

94. Miller TD, Hodge DO, Sutton JM, Grines CL, O'Keefe JH, DeWood MA, Okada RD, Fletcher WO, Gibbons RJ (1998) Usefulness of technetium-99 m sestamibi infarct size in predicting posthospital mortality following acute myocardial infarction. Am J Cardiol 81:1491-1493. https://doi.org/10.1016/S0002-9149 (98)00220-3

95. Miller TD, Christian TF, Hopfenspirger MR, Hodge DO, Gersh BJ, Gibbons RJ (1995) Infarct size after acute myocardial infarction measured by quantitative tomographic $99 \mathrm{mTc}$ sestamibi imaging predicts subsequent mortality. Circulation 92:334-341. https://doi.org/10.1161/01.CIR.92.3.334

96. Munoz C, Neji R, Cruz G, Mallia A, Jeljeli S, Reader AJ, Botnar RM, Prieto C (2017) Motion-corrected simultaneous cardiac positron emission tomography and coronary MR angiography with high acquisition efficiency. Magn Reson Med 79(1):339-350. https://doi.org/10.1002/mrm.26690

97. Murry CE, Jennings RB, Reimer KA (1986) Preconditioning with ischemia: a delay of lethal cell injury in ischemic myocardium. Circulation 74:1124-1136. https://doi.org/10.1161/01. CIR.74.5.1124

98. Nahrendorf M, Sosnovik D, Chen JW, Panizzi P, Figueiredo JL, Aikawa E, Libby P, Swirski FK, Weissleder R (2008) Activatable magnetic resonance imaging agent reports myeloperoxidase activity in healing infarcts and noninvasively detects the antiinflammatory effects of atorvastatin on ischemia-reperfusion injury. Circulation 117:1153-1160. https://doi.org/10.1161/CIRC ULATIONAHA.107.756510

99. Nensa F, Poeppel TD, Beiderwellen K, Schelhorn J, Mahabadi AA, Erbel R, Heusch P, Nassenstein K, Bockisch A, Forsting M (2013) Hybrid PET/MR imaging of the heart: feasibility and initial results. Radiology 268:366-373. https://doi.org/10.1148/ radiol.13130231

100. Oerlemans MI, Koudstaal S, Chamuleau SA, de Kleijn DP, Doevendans PA, Sluijter JP (2013) Targeting cell death in the reperfused heart: pharmacological approaches for cardioprotection. Int J Cardiol 165:410-422. https://doi.org/10.1016/j.ijcard.2012 .03 .055

101. Orogo AM, Gustafsson $\AA B$ (2013) Cell death in the myocardium: my heart won't go on. IUBMB Life 65:651-656. https:// doi.org/10.1002/iub.1180

102. Paul M, Poyan Mehr A, Kreutz R (2006) Physiology of local renin-angiotensin systems. Physiol Rev 86:747-803. https://doi. org/10.1152/physrev.00036.2005

103. Phelps ME (2000) PET: the merging of biology and imaging into molecular imaging. J Nucl Med 41:661

104. Piper HM, Meuter K, Schäfer C (2003) Cellular mechanisms of ischemia-reperfusion injury. Ann Thorac Surg 75:S644-S648. https://doi.org/10.1016/S0003-4975(02)04686-6

105. Piper H, Abdallah Y, Schäfer C (2004) The first minutes of reperfusion: a window of opportunity for cardioprotection. Cardiovasc Res 61:365-371. https://doi.org/10.1016/j.cardiores.2003.12.012

106. Pischke SE, Gustavsen A, Orrem H, Egge KH, Courivaud F, Fontenelle H, Despont A, Bongoni AK, Rieben R, Tønnessen TI (2017) Complement factor 5 blockade reduces porcine myocardial infarction size and improves immediate cardiac function. 
Basic Res Cardiol 112:20. https://doi.org/10.1007/s00395-0170610-9

107. Przyklenk K, Reddy Undyala VV, Wider J, Sala-Mercado JA, Gottlieb RA, Mentzer J, Robert M (2011) Acute induction of autophagy as a novel strategy for cardioprotection: getting to the heart of the matter. Autophagy 7:432-433. https://doi. org/10.4161/auto.7.4.14395

108. Qureshi WT, bin Nasir U (2017) Principals and clinical applications of magnetic resonance cardiac spectroscopy in heart failure. Heart Fail Rev. https://doi.org/10.1007/s10741-017-9611-

109. Reimer KA, Jennings RB (1979) The "wavefront phenomenon" of myocardial ischemic cell death. II. Transmural progression of necrosis within the framework of ischemic bed size (myocardium at risk) and collateral flow. Lab Investig 40:633-644

110. Reimer KA, Lowe JE, Rasmussen MM, Jennings RB (1977) The wavefront phenomenon of ischemic cell death. 1. Myocardial infarct size vs duration of coronary occlusion in dogs. Circulation 56:786-794. https://doi.org/10.1161/01.CIR.56.5.786

111. Ridker PM, Lüscher TF (2014) Anti-inflammatory therapies for cardiovascular disease. Eur Heart J 35:1782-1791. https://doi. org/10.1093/eurheartj/ehu203

112. Risau W (1997) Mechanisms of angiogenesis. Nature 386:671. https://doi.org/10.1038/386671a0

113. Rischpler C, Nekolla SG, Kunze KP, Schwaiger M (2015) PET/ MRI of the heart 45:234-247. https://doi.org/10.1053/j.semn uclmed.2014.12.004

114. Rischpler C, Dirschinger RJ, Nekolla SG, Kossmann H, Nicolosi S, Hanus F, van Marwick S, Kunze KP, Meinicke A, Gotze K, Kastrati A, Langwieser N, Ibrahim T, Nahrendorf M, Schwaiger M, Laugwitz KL (2016) Prospective evaluation of 18F-fluorodeoxyglucose uptake in postischemic myocardium by simultaneous positron emission tomography/magnetic resonance imaging as a prognostic marker of functional outcome. Circ Cardiovasc Imaging 9:e004316. https://doi.org/10.1161/CIRCIMAG ING.115.004316

115. Rodriguez-Porcel M, Cai W, Gheysens O, Willmann JK, Chen K, Wang H, Chen IY, He L, Wu JC, Li ZB, Mohamedali KA, Kim S, Rosenblum MG, Chen X, Gambhir SS (2008) Imaging of VEGF receptor in a rat myocardial infarction model using PET. J Nucl Med 49:667-673. https://doi.org/10.2967/jnumed.107.040576

116. Rogers IS, Nasir K, Figueroa AL, Cury RC, Hoffmann U, Vermylen DA, Brady TJ, Tawakol A (2010) Feasibility of FDG imaging of the coronary arteries: comparison between acute coronary syndrome and stable angina. JACC Cardiovasc Imaging 3:388-397. https://doi.org/10.1016/j.jcmg.2010.01.004

117. Schinkel AF, Poldermans D, Elhendy A, Bax JJ (2007) Assessment of myocardial viability in patients with heart failure. J Nucl Med 48:1135-1146. https://doi.org/10.2967/jnumed.106.038851

118. Schluter KD, Jakob G, Ruiz-Meana M, Garcia-Dorado D, Piper HM (1996) Protection of reoxygenated cardiomyocytes against osmotic fragility by nitric oxide donors. Am J Physiol 271:H428-H434

119. Sherif HM, Saraste A, Nekolla SG, Weidl E, Reder S, Tapfer A, Rudelius M, Higuchi T, Botnar RM, Wester HJ, Schwaiger M (2012) Molecular imaging of early alphavbeta3 integrin expression predicts long-term left-ventricle remodeling after myocardial infarction in rats. J Nucl Med 53:318-323. https://doi. org/10.2967/jnumed.111.091652

120. Shirani J, Dilsizian V (2008) Imaging left ventricular remodeling: targeting the neurohumoral axis. Nat Clin Pract Cardiovasc Med 5:S57-S62. https://doi.org/10.1038/ncpcardio1244

121. Shirani J, Loredo ML, Eckelman WC, Jagoda EM, Dilsizian V (2005) Imaging the renin-angiotensin-aldosterone system in the heart. Curr Heart Fail Rep 2:78-86. https://doi.org/10.1038/ncpc $\operatorname{ardio} 1244$
122. Singh KK, Yanagawa B, Quan A, Wang R, Garg A, Khan R, Pan Y, Wheatcroft MD, Lovren F, Teoh H (2014) Autophagy gene fingerprint in human ischemia and reperfusion. J Thorac Cardiovasc Surg 147(1065-1072):e1. https://doi.org/10.1016/j.jtcv s.2013.04.042

123. Sinusas AJ, Thomas JD, Mills G (2011) The future of molecular imaging. JACC Cardiovasc Imaging 4:799-806. https://doi. org/10.1016/j.jcmg.2011.05.003

124. Skyschally A, Schulz R, Heusch G (2008) Pathophysiology of myocardial infarction. Herz 33:88-100. https://doi.org/10.1007/ s00059-008-3101-9

125. Sosnovik DE, Wang R, Dai G, Reese TG, Wedeen VJ (2009) Diffusion MR tractography of the heart. J Cardiovasc Magn Reson 11:47. https://doi.org/10.1186/1532-429X-11-47

126. Sosnovik DE, Nahrendorf M, Weissleder R (2008) Magnetic nanoparticles for MR imaging: agents, techniques and cardiovascular applications. Basic Res Cardiol 103:122-130. https:// doi.org/10.1007/s00395-008-0710-7

127. Sosnovik DE, Schellenberger EA, Nahrendorf M, Novikov MS, Matsui T, Dai G, Reynolds F, Grazette L, Rosenzweig A, Weissleder R (2005) Magnetic resonance imaging of cardiomyocyte apoptosis with a novel magneto-optical nanoparticle. Magn Reson Med 54:718-724. https://doi.org/10.1002/mrm.20617

128. Sosnovik DE, Garanger E, Aikawa E, Nahrendorf M, Figuiredo JL, Dai G, Reynolds F, Rosenzweig A, Weissleder R, Josephson L (2009) Molecular MRI of cardiomyocyte apoptosis with simultaneous delayed-enhancement MRI distinguishes apoptotic and necrotic myocytes in vivo: potential for midmyocardial salvage in acute ischemia. Circ Cardiovasc Imaging 2:460-467. https:// doi.org/10.1161/CIRCIMAGING.109.859678

129. Sosnovik DE, Wang R, Dai G, Wang T, Aikawa E, Novikov M, Rosenzweig A, Gilbert RJ, Wedeen VJ (2009) Diffusion spectrum MRI tractography reveals the presence of a complex network of residual myofibers in infarcted myocardium. Circ Cardiovasc Imaging 2:206-212. https://doi.org/10.1161/CIRC IMAGING.108.815050

130. Sosnovik DE, Nahrendorf M, Weissleder R (2007) Molecular magnetic resonance imaging in cardiovascular medicine. Circulation 115:2076-2086. https://doi.org/10.1161/CIRCULATIONA HA.106.658930

131. Spinale FG (2002) Matrix metalloproteinases: regulation and dysregulation in the failing heart. Circ Res 90:520-530. https:// doi.org/10.1161/01.RES.0000013290.12884.A3

132. Su H, Spinale FG, Dobrucki LW, Song J, Hua J, Sweterlitsch S, Dione DP, Cavaliere P, Chow C, Bourke BN, Hu XY, Azure M, Yalamanchili P, Liu R, Cheesman EH, Robinson S, Edwards DS, Sinusas AJ (2005) Noninvasive targeted imaging of matrix metalloproteinase activation in a murine model of postinfarction remodeling. Circulation 112:3157-3167. https://doi.org/10.1161 /CIRCULATIONAHA.105.583021

133. Sun Y, Mendelsohn FA (1991) Angiotensin converting enzyme inhibition in heart, kidney, and serum studied ex vivo after administration of zofenopril, captopril, and lisinopril. J Cardiovasc Pharmacol 18:478-486

134. Swirski FK, Nahrendorf M (2013) Leukocyte behavior in atherosclerosis, myocardial infarction, and heart failure. Science 339:161-166. https://doi.org/10.1126/science.1230719

135. Szabo Z, Speth RC, Brown PR, Kerenyi L, Kao PF, Mathews WB, Ravert HT, Hilton J, Rauseo P, Dannals RF, Zheng W, Lee S, Sandberg K (2001) Use of positron emission tomography to study AT1 receptor regulation in vivo. J Am Soc Nephrol 12:1350-1358

136. Tani M, Neely JR (1989) Role of intracellular $\mathrm{Na}^{+}$in $\mathrm{Ca}_{2}^{+}$ overload and depressed recovery of ventricular function of reperfused ischemic rat hearts. Possible involvement of $\mathrm{H}^{+}-\mathrm{Na}^{+}$ 
and $\mathrm{Na}^{+}-\mathrm{Ca}^{2+}$ exchange. Circ Res 65:1045-1056. https://doi. org/10.1161/01.RES.65.4.1045

137. Thackeray JT, Bankstahl JP, Wang Y, Wollert KC, Bengel FM (2016) Targeting amino acid metabolism for molecular imaging of inflammation early after myocardial infarction. Theranostics 6:1768. https://doi.org/10.7150/thno.15929

138. Thackeray JT, Bankstahl JP, Wang Y, Wollert KC, Bengel FM (2015) Clinically relevant strategies for lowering cardiomyocyte glucose uptake for 18F-FDG imaging of myocardial inflammation in mice. Eur J Nucl Med Mol Imaging 42:771-780. https:// doi.org/10.1007/s00259-014-2956-7

139. Thackeray JT, Derlin T, Haghikia A, Napp LC, Wang Y, Ross TL, Schäfer A, Tillmanns J, Wester HJ, Wollert KC (2015) Molecular imaging of the chemokine receptor CXCR4 after acute myocardial infarction. JACC Cardiovasc Imaging 8:1417-1426. https:// doi.org/10.1016/j.jcmg.2015.09.008

140. Tyagi SC, Bheemanathini VS, Mandi D, Reddy HK, Voelker DJ (1996) Role of extracellular matrix metalloproteinases in cardiac remodelling. Heart Fail Rev 1:73-80. https://doi.org/10.1007/ BF00128558

141. Uitterdijk A, Springeling T, Hermans KC, Merkus D, de Beer VJ, Gorsse-Bakker C, Mokelke E, Daskalopoulos EP, Wielopolski PA, Cleutjens JP (2017) Intermittent pacing therapy favorably modulates infarct remodeling. Basic Res Cardiol 112:28. http s://doi.org/10.1007/s00395-017-0616-3

142. Underwood S, Anagnostopoulos C, Cerqueira M, Ell P, Flint E, Harbinson M, Kelion A, Al-Mohammad A, Prvulovich E, Shaw L (2004) Myocardial perfusion scintigraphy: the evidence. Eur J Nucl Med Mol Imaging 31:261-291. https://doi.org/10.1007/ s00259-003-1344-5

143. Van Den Borne SWM, Diez J, Blankesteijn WM, Verjans J, Hofstra L, Narula J (2010) Myocardial remodeling after infarction: the role of myofibroblasts. Nat Rev Cardiol 7:30-37. https://doi. org/10.1038/nrcardio.2009.199

144. van den Borne SWM, Isobe S, Verjans JW, Petrov A, Lovhaug D, Li P, Zandbergen HR, Ni Y, Frederik P, Zhou J (2008) Molecular imaging of interstitial alterations in remodeling myocardium after myocardial infarction. J Am Coll Cardiol 52:2017-2028. https://doi.org/10.1016/j.jacc.2008.07.067

145. van der Laan AM, Nahrendorf M, Piek JJ (2012) Healing and adverse remodelling after acute myocardial infarction: role of the cellular immune response. Heart 98:1384-1390. https://doi. org/10.1136/heartjnl-2012-301623

146. Vandenabeele P, Galluzzi L, Berghe TV, Kroemer G (2010) Molecular mechanisms of necroptosis: an ordered cellular explosion. Nat Rev Mol Cell Biol 11:700-714. https://doi.org/10.1038 /nrm2970

147. Vanhoutte L, Gerber BL, Gallez B, Po C, Magat J, Jean-Luc B, Feron O, Moniotte S (2016) High field magnetic resonance imaging of rodents in cardiovascular research. Basic Res Cardiol 111:1-20. https://doi.org/10.1007/s00395-016-0565-2

148. Vasilyev N, Williams T, Brennan ML, Unzek S, Zhou X, Heinecke JW, Spitz DR, Topol EJ, Hazen SL, Penn MS (2005) Myeloperoxidase-generated oxidants modulate left ventricular remodeling but not infarct size after myocardial infarction. Circulation 112:2812-2820. https://doi.org/10.1161/CIRCULATIONA HA. 105.542340
149. Verjans JW, Wolters SL, Lax M, Laufer W, Boersma H, Kemerink GK, Lovhaug D, Gordon P, Reutelingsperger C, Teule J (2007) Imaging $\alpha v \beta 3 / \beta 5$ integrin upregulation in patients after myocardial infarction. Circulation 116:II_740

150. Verjans JW, Lovhaug D, Narula N, Petrov AD, Indrevoll B, Bjurgert E, Krasieva TB, Petersen LB, Kindberg GM, Solbakken M (2008) Noninvasive imaging of angiotensin receptors after myocardial infarction. JACC Cardiovasc Imaging 1:354-362. https://doi.org/10.1016/j.jemg.2007.11.007

151. Walls MC, Verhaert D, Min JK, Raman SV (2011) Myocardial edema imaging in acute coronary syndromes. J Magn Reson Imaging 34:1243-1250. https://doi.org/10.1002/jmri.22737

152. Weiger M, Pruessmann KP, Boesiger P (2000) Cardiac real-time imaging using SENSE. Magn Reson Med 43:177-184. https:// doi.org/10.1002/(SICI)1522-2594(200002)43:23.0.CO;2-1

153. Weiss RG, Bottomley PA, Hardy CJ, Gerstenblith G (1990) Regional myocardial metabolism of high-energy phosphates during isometric exercise in patients with coronary artery disease. $\mathrm{N}$ Engl J Med 323:1593-1600. https://doi.org/10.1056/NEJM1990 12063232304

154. Weiss JN, Korge P, Honda HM, Ping P (2003) Role of the mitochondrial permeability transition in myocardial disease. Circ Res 93:292-301. https://doi.org/10.1161/01.RES.0000087542.2697 $1 . \mathrm{D} 4$

155. Whatling C, McPheat W, Hurt-Camejo E (2004) Matrix management: assigning different roles for MMP-2 and MMP-9 in vascular remodeling. Arterioscler Thromb Vasc Biol 24:10-11. https://doi.org/10.1161/01.ATV.0000100562.63144.C1

156. Wilson EM, Moainie SL, Baskin JM, Lowry AS, Deschamps AM, Mukherjee R, Guy TS, St John-Sutton MG, Gorman JH III, Edmunds LH Jr, Gorman RC, Spinale FG (2003) Region- and type-specific induction of matrix metalloproteinases in postmyocardial infarction remodeling. Circulation 107:2857-2863. https://doi.org/10.1161/01.CIR.0000068375.40887.FA

157. Winter PM, Morawski AM, Caruthers SD, Fuhrhop RW, Zhang H, Williams TA, Allen JS, Lacy EK, Robertson JD, Lanza GM, Wickline SA (2003) Molecular imaging of angiogenesis in earlystage atherosclerosis with alpha(v)beta3-integrin-targeted nanoparticles. Circulation 108:2270-2274. https://doi.org/10.1161/01. CIR.0000093185.16083.95

158. Wisenberg G, Prato FS, Carroll SE, Turner KL, Marshall T (1988) Serial nuclear magnetic resonance imaging of acute myocardial infarction with and without reperfusion. Am Heart J 115:510-518. https://doi.org/10.1016/0002-8703(88)90798-3

159. Yellon DM, Hausenloy DJ (2007) Myocardial reperfusion injury. N Engl J Med 357:1121-1135. https://doi.org/10.1056/NEJM $\mathrm{ra} 071667$

160. Zhao ZQ, Corvera JS, Halkos ME, Kerendi F, Wang NP, Guyton RA, Vinten-Johansen J (2003) Inhibition of myocardial injury by ischemic postconditioning during reperfusion: comparison with ischemic preconditioning. Am J Physiol Heart Circ Physiol 285:H579-H588. https://doi.org/10.1152/ajpheart.01064.2002

161. Zhou W, Yuan J (2014) SnapShot: necroptosis. Cell 158(464464):e1. https://doi.org/10.1016/j.cell.2014.06.041 